\title{
SOME PHYSICAL PROPERTIES OF LEVULOSE AND ITS ESTIMATION BY COPPER REDUCTION METHODS
}

\author{
By Richard F. Jackson and Joseph A. Mathews
}

\section{ABSTRACT}

Fundamental physical properties of levulose have been determined in order to facilitate its quantitative determination. Densities of aqueous solutions are given at $20^{\circ}$ and $25^{\circ} \mathrm{C}$. for concentrations 0 to 70 per cent. Expansions have been measured over a $50^{\circ}$ temperature interval. The density of crystalline levulose is shown to be 1.598. Refractive indices of levulose solutions have been measured at $20^{\circ}$ and $25^{\circ} \mathrm{C}$. between 0 and 90 per cent concentration. The saccharimetric rotations of levulose solutions have been measured at $20^{\circ}$ and $25^{\circ}$ and the change of rotation over a $50^{\circ}$ interval of temperature determined.

Copper reduction methods for the determination of levulose have been studied. Nyns's selective method for the estimation of levulose has been modified by specifying a period of 75 minutes' digestion at $55^{\circ} \mathrm{C}$. (instead of 150 minutes at $49^{\circ}$ C.). An electrometric method for the estimation of cuprous oxide is described. The errors of analysis have been reduced by attention to details.

Simplified methods of computation have been devised which permit the rapid calculation of the levulose content of sugar mixtures.

CONTENTS

I. Introductory

II. Purification of levulose

III. Densimetric measurements

1. Densities of levulose solutions

2. Mean expansion of levulose solutions between $20^{\circ}$ and $25^{\circ} \mathrm{C}_{-} \quad 408$

3. Correction of Brix hydrometers for levulose solutions..... 410

4. Expansion of levulose solutions at wide temperature intervals_ $\quad 410$

5. Density of crystalline levulose ...... 411

IV. Refractive indices of levulose solutions

V. Saccharimetric normal weight of levulose

1. Measurement of saccharimetric rotation ............ 415

2. Change of polarization of levulose between widely separated

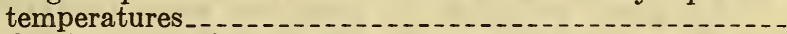

VI. Copper reduction methods for total reducing sugar

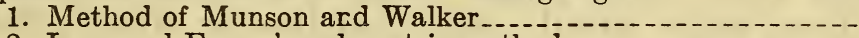

2. Lane and Eynon's volumetric method

VII. Biourge and Nyns's selective determination of levulose.

1. Introductory _.

2. Effect of time and temperature upon the reduction reaction.-

3. An electrometric method for the determination of reduced copper ..............

4. Standard solutions

5. Analytical procedure

6. Determination of copper-levulose equivalents

7. Discussion of errors.

8. Effect of dextrose.

9. Effect of sucrose.

VIII. Analysis of sugar mixtures containing levulose

1. Introductory

2. Determination of levulose and dextrose in mixtures by polarization and Lane and Eynon titration. The Mathews formula..................................

3. Calculation of levulose in a levulose-dextrose mixture from any method of total reducing sugar analysis and the modified Nyns method.

4. Calculation of levulose in a levulose-dextrose mixture from Lane and Eynon titration and the modified Nyns method. (1) 


\section{INTRODUCTORY}

The ketose sugar, levulose, or $d$-fructose, promises in the future to assume an importance in some degree commensurate with its abundance and intrinsic value. It is widely distributed in natural products in which it may occur existing in a free state, or combined with other hexoses to form compound sugars, or condensed to form polysaccharides of high molecular weight. It has been shown in a previous article $^{1}$ that crystalline levulose can be prepared from potentially abundant sources by a process capable of industrial development. Such a process requires accurate and rapid methods of analytical control. Numerous foodstuffs, many of them long-established articles of diet, contain levulose whose content has hitherto been but roughly gaged.

The accurate assay of all these materials requires a quantitative knowledge of the fundamental properties of pure levulose and its aqueous solutions. The present communication is intended to contribute data on the physical properties of levulose and on reduction methods for its estimation. While the investigation can not be considered exhaustive, each step has been carried out with the intention of meeting the needs of ordinary analytical precision.

\section{PURIFICATION OF LEVULOSE}

The levulose which served as the main source of supply for the experiments described in the present article had previously been prepared from the juices of the Jerusalem artichoke by hydrolysis with sulphuric acid, defecation and precipitation with lime, and crystallization from aqueous solution by the method described by Jackson, Silsbee, and Proffitt. ${ }^{2}$ It consisted of relatively large wellformed tilted cubes and was already approximately 99.5 per cent pure. Additional supplies of levulose were derived from inulin obtained from dahlia juices. From the inulin the levulose was crystallized either directly after hydrolysis or after hydrolysis and precipitation with lime.

For further purification the sugar was dissolved in about an equal weight of water, treated with carbon, filtered, and evaporated in a vacuum to a thick sirup. The sirup was transferred to a glass jar, admixed with alcohol, seeded, and the jar tumbled end over end in a motor-driven apparatus until crystallization was complete. The crystals were purged in a centrifugal machine and thoroughly washed with alcohol. Characteristic experimental results are assembled in Table 1.

TABLE 1.-Recrystallization of levulose from alcoholic solution

\begin{tabular}{|c|c|c|c|c|c|c|c|}
\hline \multirow{2}{*}{$\begin{array}{c}n_{D}^{20} \\
\text { thick } \\
\text { sirup }\end{array}$} & \multirow{2}{*}{ Levulose } & \multirow{2}{*}{$\begin{array}{l}\text { Weight } \\
\text { of sirup }\end{array}$} & \multirow{2}{*}{$\begin{array}{l}\text { Calcu- } \\
\text { lated } \\
\text { welght } \\
\text { of levu- } \\
\text { lose }\end{array}$} & \multirow{2}{*}{$\begin{array}{l}\text { Strength } \\
\text { of alco- } \\
\text { hol (by } \\
\text { volume) }\end{array}$} & \multirow{2}{*}{$\begin{array}{l}\text { Weight } \\
\text { of alco- } \\
\text { hol }\end{array}$} & \multicolumn{2}{|c|}{$\begin{array}{l}\text { Yield of dry } \\
\text { crystals }\end{array}$} \\
\hline & & & & & & Weight & Per cont \\
\hline $\begin{array}{l}1.508 \\
1.508 \\
1.5133\end{array}$ & $\begin{array}{c}\text { Per cent } \\
89.2 \\
89.2 \\
91.3\end{array}$ & $\begin{array}{r}g \\
897 \\
1,078 \\
359\end{array}$ & $\begin{array}{l}g \\
800 \\
982 \\
328\end{array}$ & $\begin{array}{c}\text { Per cent } \\
95 \\
100 \\
95\end{array}$ & $\begin{array}{l}g \\
346 \\
353 \\
144\end{array}$ & $\begin{array}{l}g \\
482 \\
735 \\
211\end{array}$ & $\begin{array}{l}60 \\
76 \\
64\end{array}$ \\
\hline
\end{tabular}

1 Jackson, Silsbee, Proffitt, B. S. Sci. Papers No. 519, vol. 20, p. 519, 1926.

2 See footnote 1. 
The method of purification was so effective that a single recrystallization of levulose, already fairly pure, produced samples which in general could not be distinguished by our measurements from those recrystallized two or three times. All samples which were used for the measurements of physical properties were recrystallized at least twice.

After a period of air drying the crystals were further dried at about $50^{\circ} \mathrm{C}$. and were stored in a desiccator. Although levulose is somewhat hygroscopic, the pure crystalline substance can apparently be completely dried by simple measures. Samples prepared as described above usually contained no more than 0.02 per cent of residual moisture. Extensive experimentation showed that this could be eliminated by warming to $50^{\circ} \mathrm{C}$. in a thin layer for about two hours. Such a sample was further heated at $70^{\circ} \mathrm{C}$. for about 30 hours without further loss. It was then heated at $60^{\circ}$ to $70^{\circ} \mathrm{C}$. in a vacuum chamber without loss of weight. If heated to much higher temperatures the substance suffers loss of weight as a result of decomposition. ${ }^{3}$

\section{DENSIMETRIC MEASUREMENTS}

\section{DENSITIES OF LEVULOSE SOLUTIONS}

For a relatively short range of concentrations the densities of aqueous solutions of levulose have previously been determined by a number of investigators, ${ }^{4}$ usually incidentally to measurements of its rotatory power. For the purpose of extending the range of concentrations and of aiding in the critical selection of valid existing data aditional density measurements have been made and are reported below.

Densities were measured in the present investigation by means of flasks whose necks, $6 \mathrm{~mm}$ inside diameter, were graduated in 10 divisions at intervals of $0.02 \mathrm{ml}$. The volume reading could be made to one-tenth of one of these divisions thus permitting a precision of two units in the fifth decimal of density for a flask holding $100 \mathrm{ml}$. The largest of these flasks contained at the lowest graduation mark $126.333 \mathrm{ml}$ at $20^{\circ} \mathrm{C}$. For concentrations up to 24 per cent this flask was used exclusively. For concentrations from 30 to 60 per cent at least one measurement was made with this flask at 10 per cent intervals, while additional measurements were made with flasks containing 48.461 and $25.303 \mathrm{ml}$, respectively. The flasks were calibrated frequently at $20^{\circ}$ and $25^{\circ} \mathrm{C}$. and were found to have kept a constant volume within $0.002 \mathrm{ml}$ during the course of the investigation.

The volumes of the smaller flasks could be observed with the same precision as that of the larger flask, but the percentage errors of observation became three and five times as great, respectively. It was, therefore, necessary to weight the observations in accordance with their respective accuracies. Th, ${ }_{1}$ was done by summing up the weights of levulose and of solution and the volumes of solutions which had approximately the same concentration, thus obtaining in effect one large solution for computation of data. In these averaged

3 The conclusions respecting the drying of levulose are in harmony with previous work on this subject. For summary of previous work see Browne's Handbook of Sugar Analysis, p. 20. John Wiley \& Sons, New York, 1912.

- Landolt u. Börnstein Tabellen, vol. 1, p. 468, 1923. 
values (Table 3 ) the data obtained with the larger flasks predominated in proportion to their volumes.

The levulose, prepared and dried as previously described, was introduced into the weighed flask and weighed. The sugar was dissolved and the air removed from the solution by warming slightly and applying a vacuum, care being exercised to avoid loss by spattering. Water was then added to some point within the graduated scale and after mixing by a rotary motion the flask was placed in a thermostat for at least a half hour before the final observation of volume. The neck of the flask was dried by a stream of filtered air. Since the manipulation was time-consuming, mutarotation was complete before the final observation of volume.

The volumes of all solutions below 20 per cent concentration were measured at $20^{\circ}$ and $25^{\circ} \mathrm{C}$. Solutions of higher concentrations were measured at $20^{\circ}$ and at $25^{\circ} \mathrm{C}$. or at some neighboring temperature which was carefully observed.

At the time of each weighing the density of the air in the balance case was determined by weighing a glass bulb whose true mass had been determined by A. T. Pienkowsky, of this bureau. All weights were reduced to vacuum, the density of levulose being assumed 1.598 in accordance with a determination described below.

The data are assembled in Tables 2 and 3. Sylvia Mi. Goergen has made a least square adjustment of the data in Table 2 and computed the formulas (1) and (2).

$$
\begin{aligned}
& D_{4}^{20}=0.99823+0.0038893 p+0.0000140 p^{2} \\
& D_{4}^{25}=0.99708+0.0038557 p+0.0000139 p^{2}
\end{aligned}
$$

which are valid between 0 and 20 per cent levulose.

The observed densities of the dilute solutions in Table 2 show a mean deviation from the formulas of two units in the fifth decimal for both temperatures. We, therefore, believe that the formulas are valid to some units in the fifth decimal and have solved them for 1 per cent intervals between 0 and 20 per cent levulose for purposes of tabulation. These calculated densities are given in Table 18, p. 437.

The data for the higher concentrations are given in Table 3. An adjustment was made by the method of least squares, yielding the formula,

$$
D_{4}^{20}=0.99936+0.0037842 \mathrm{p}+0.00001636 p^{2}
$$

which is valid between 24 and 70 per cent. A comparison of the densities calculated from the formula with the experimental data in Table 3 discloses a mean deviation of 6 units in the fifth decimal. In our judgment the fourth decimal of the adjusted densities is reliable within about one-half a unit and we have, therefore, solved the formula between 24 and 71 per cent for 1 per cent intervals to the fourth decimal for tabulation in Table 18, p. 437. Formulas (1) and (3) yielded essentially identical values between 20 and 24 per cent. 


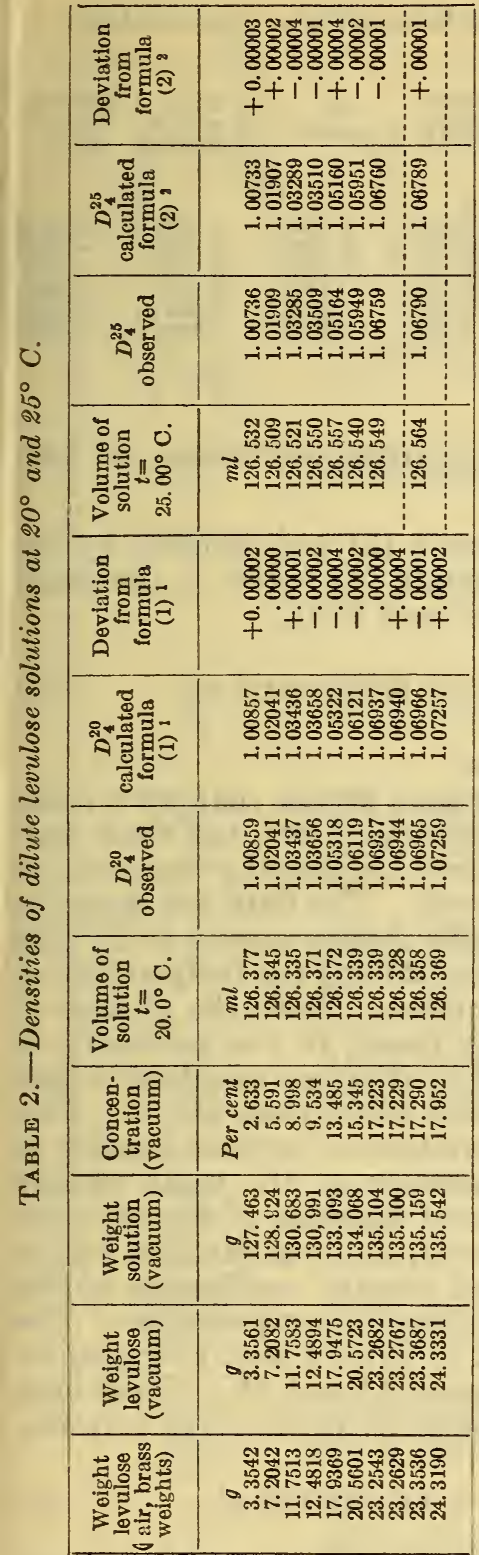


TABLE 3.-Densities at $20^{\circ} \mathrm{C}$. of levulose solutions of higher concentrations

\begin{tabular}{|c|c|c|c|c|c|c|c|}
\hline $\begin{array}{c}\text { Number of deter- } \\
\text { minations }\end{array}$ & $\begin{array}{l}\text { Weight } \\
\text { levulose } \\
\text { (vacuum) }\end{array}$ & $\begin{array}{c}\text { Weight } \\
\text { solution } \\
\text { (vacuum) }\end{array}$ & $\begin{array}{c}\text { Concentra- } \\
\text { tion }\end{array}$ & $\begin{array}{l}\text { Volume } \\
\text { solution } \\
\text { at } 20.0^{\circ} \mathrm{C} \text {. }\end{array}$ & $\underset{\text { observed }}{D_{4}^{20}}$ & $\begin{array}{c}D_{4}^{20} \\
\text { calculated } \\
\text { formula (3) }\end{array}$ & $\begin{array}{l}\text { Residual, } \\
\text { Obs.-- } \\
\text { Calcd. }\end{array}$ \\
\hline $\begin{array}{l}1 \\
2 \\
3 \\
3 \\
2\end{array}$ & $\begin{array}{r}\text { g. } \\
34.0572 \\
61.9334 \\
145.2537 \\
173.6622 \\
117.1697 \\
23.4329\end{array}$ & $\begin{array}{r}g \\
139.282 \\
198.156 \\
355.746 \\
342.833 \\
195.000 \\
\mathbf{3 3 .} 886\end{array}$ & $\begin{array}{c}\text { Per cent } \\
24.452 \\
31.255 \\
40.831 \\
50.655 \\
60.087 \\
69.152\end{array}$ & $\begin{array}{l}m l . \\
126.418 \\
174.813 \\
301.193 \\
278.040 \\
151.643 \\
25.303\end{array}$ & $\begin{array}{l}\text { 1. } 10176 \\
1.13353 \\
1.18112 \\
1.23303 \\
1.28591 \\
1.33921\end{array}$ & $\begin{array}{l}1.10167 \\
1.13361 \\
1.18114 \\
1.23302 \\
1.28579 \\
1.33927\end{array}$ & $\begin{array}{r}+0.00009 \\
-.00008 \\
-.00002 \\
+.00001 \\
+.00012 \\
-.00006\end{array}$ \\
\hline
\end{tabular}

1 (3) $D_{4}^{20}=0.99936+0.0037842 \mathrm{p}+0.00001636 p^{2}$.

\section{MEAN EXPANSION OF LEVULOSE SOLUTIONS BETWEEN $20^{\circ}$ AND} $25^{\circ} \mathrm{C}$.

By subtracting formula (1) from formula (2) and dividing by the difference in temperature we obtain formula (4), which is the mean change of density per degree between $20^{\circ}$ and $25^{\circ} \mathrm{C}$.

$$
\frac{\Delta D}{\Delta t}=-\left(0.000231+0.00000672 \mathrm{p}-0.0000000224 p^{2}\right)
$$

valid between 0 and 20 per cent levulose.

The solutions of concentration higher than 20 per cent were made up primarily for the determination of density at $20^{\circ}$, but their densities were also measured at $25^{\circ} \mathrm{C}$. or some neighboring temperature which was in each case accurately observed. The data are shown in Table 4. In order to adjust these density measurements to $25^{\circ}$ the mean change of density per degree between 20 and the temperature of observation was computed for each solution. Since the change of density with temperature is not exactly linear, it was necessary to apply a correction to the measurements of those solutions whose densities were determined at temperatures other than $25^{\circ} \mathrm{C}$. This was computed by assuming that the deviation of levulose density at other temperatures was the same percentage of the mean change between $20^{\circ}$ and $25^{\circ} \mathrm{C}$. as the deviation of densities of sucrose solutions of similar concentration. This assumption was justified by the agreement shown between the corrected density coefficients of the same levulose solutions observed at different temperatures. The corrected coefficients given in column 12 of Table 4 were averaged for groups of similar concentrations in columns 13 and 14 . These data were adjusted by the method of least squares yielding the formula,

$$
\frac{\Delta D}{\Delta t}=-\left(0.0002145+0.00000795 \mathrm{p}-0.0000000136 p^{2}\right)
$$

which is valid between 20 and 70 per cent levulose and $20^{\circ}$ and $25^{\circ} \mathrm{C}$. By application of this formula to the densities at $20^{\circ} \mathrm{C}$. the data at $25^{\circ} \mathrm{C}$. were computed to four decimals and are included in Table 18, p. 437. 


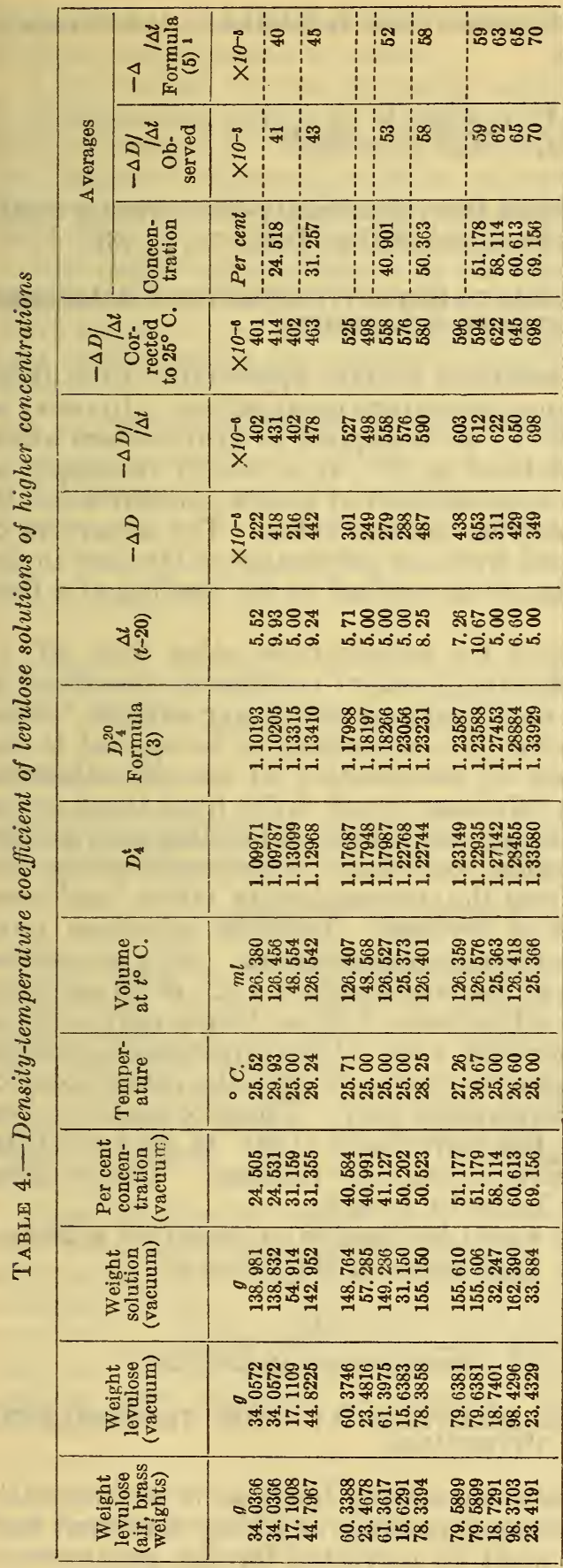


The change of volume with temperature is related to the change of density with temperature by

$$
\frac{d V}{d t}=-\frac{d D}{d t} \times \frac{V}{D}=-\frac{d D}{d t} \times \frac{1}{D}, \text { since } V=1
$$

Expansion coefficients calculated from the density-temperature coefficients by this equation have been included in Table 18, p. 437 .

\section{CORRECTIONS TO BE APPLIED TO BRIX HYDROMETERS IMMERSED IN LEVULOSE SOLUTIONS}

The densities of levulose solutions deviate appreciably from those of sucrose solutions of the same percentage composition. In order to calculate the correction at $20^{\circ} \mathrm{C}$. to be applied to hydrometers which are standard for sucrose solutions at $20^{\circ}$, it is merely necessary to compute the "Brix" of a levulose solution of known concentration by referring its density to the sucrose density table. The departure of the percentage of sucrose found from the percentage of levulose in the given solution is the correction to be applied to the reading of a Brix hydrometer.

To determine the corrections for temperatures other than $20^{\circ} \mathrm{C}$. we have available the density-temperature coefficients described in the previous section. The handbooks on cane sugar analysis ${ }^{5}$ have, in conveniently tabulated form, the corrections to be applied to the Brix hydrometer for changes of temperature of sucrose solutions. The corrections for levulose solutions would differ from these in the ratio of the respective expansion coefficients of levulose and sucrose solutions. The mean expansion coefficients of sucrose between $20^{\circ}$ and $25^{\circ} \mathrm{C}$. were calculated from the sucrose density tables ${ }^{6}$ and compared with the coefficients of levulose. Levulose solutions have higher expansion coefficients than sucrose solutions. At a concentration of 10 per cent the ratio of the coefficients is 1.12 ; at 20 per cent, 1.20 ; at 30 per cent, 1.22 ; at 40 per cent, 1.19 ; at 50 per cent, 1.23 ; at 60 per cent, 1.28 ; and at 70 per cent, 1.33 . The corrections for sucrose were multiplied by these respective ratios to give the corrections for levulose for the change of temperature only. These corrections were then added algebraically to the corrections at $20^{\circ}$ to give the total corrections to be applied to Brix hydrometer readings. The resulting corrections are tabulated in Table 19, p. 438.

From the data at hand it would be feasible to construct a Baumé scale of levulose densities by application of the formula ${ }^{7}$

$$
\text { Degrees Baumé }=145-\frac{145}{\text { Specific gravity }\left(20^{\circ} / 20^{\circ}\right)}
$$

\section{EXPANSION OF LEVULOSE SOLUTIONS AT WIDE TEMPERATURE INTERVALS}

In the analysis of solutions containing levulose it is frequently necessary to determine polariscopic readings at widely divergent temperatures. These readings must be corrected for the expansion of

3 For example, B. S. Circular No. 44, p. 128.

6 Landolt u. Börnstein Tabellen, vol. 1, p. 463, 1923.

7 Bates and Bearce, B. S. Tech. Paper No. 115. 
the solution in order that both readings may be referred to the same volume concentration of solute.

A convenient volume-measuring apparatus was made by sealing a $5 \mathrm{ml}$ graduated pipette to a long narrow glass bulb. This was carefully calibrated by weighing it filled with distilled water and reading the change of volume at various temperature intervals up to $100^{\circ} \mathrm{C}$. The accuracy of the calibration was attested by the fact that the glass itself showed a constant cubical expansion coefficient.

For analytical methods it is convenient to use the temperature interval $20^{\circ}$ to $70^{\circ} \mathrm{C}$. As indicated in Table 5 a mean change of $0.044 \mathrm{ml}$ per $100 \mathrm{ml}$ per ${ }^{\circ} \mathrm{C}$. may be taken for solutions of about 5 per cent concentration and 0.045 for about 18 per cent concentration.

TABLE 5.-Expansion of solutions between wide temperature limits

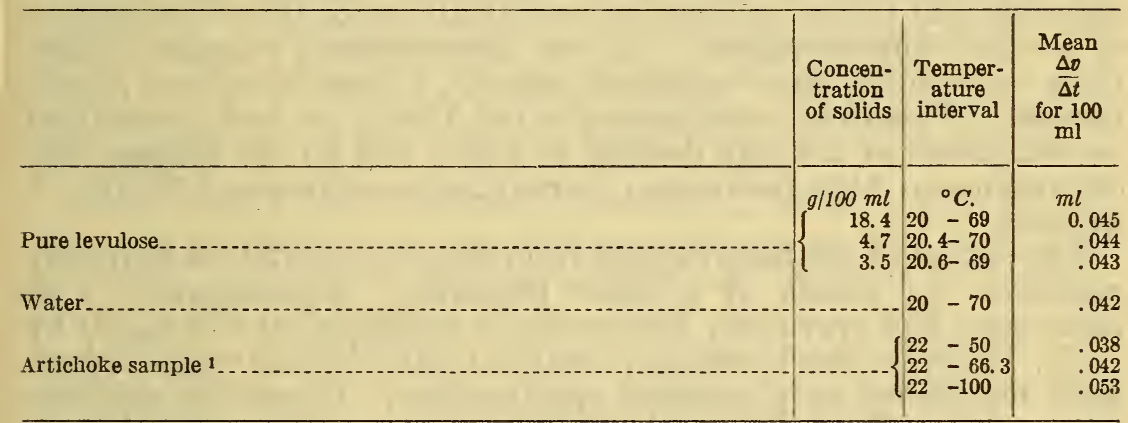

1 An $80 \mathrm{~g}$ sample of ground fresh artichokes hydrolyzed with $\mathrm{HCl}$, defecated, made to $325 \mathrm{ml}$, and filtered in preparation for analysis.

\section{DENSITY OF CRYSTALLINE LEVULOSE}

Since many of the calculations in the present investigation required a reduction of the weights of crystalline levulose to a vacuum, a determination of the density of the cubelike crystal form of levulose was considered necessary. ${ }^{8}$

For the measurement of density a flask was used of about $20 \mathrm{ml}$ volume with a neck $3 \mathrm{~mm}$ in diameter graduated in 10 divisions of $0.0056 \mathrm{ml}$ each. The volume could be observed to a precision of $0.001 \mathrm{ml}$.

Pure dry levulose was weighed in the calibrated flask, and the flask was filled with dry toluene saturated with levulose at $20^{\circ} \mathrm{C}$, Air trapped in the crystals was removed by applying gentle suction while rotating the flask. The mixture was made to volume at $20.0^{\circ} \mathrm{C}$. and reweighed. Three independent determinations of the density of levulose and of the toluene saturated with levulose were made. All weights were corrected to vacuum. The density $\left(\begin{array}{l}20 \\ 4\end{array}\right)$ was found to be 1.598 .

${ }^{8}$ Previously announced values: $d \stackrel{17.8}{1}, 1.669$ (crystal form not specified), Int. Critical Tables, vol. 1, p. 203, Index No. 1674; $d_{4}^{0}, 1.555$ (needles), Handbook of Chemistry and Physics, Hodgman and Lange, Chem. Rubber Co., 13 ed., p. 356, 1928. 
TABLE 6.-Density of crystalline levulose

\begin{tabular}{|c|c|c|c|c|c|c|c|c|}
\hline $\begin{array}{c}\text { Weight } \\
\text { pure } \\
\text { tolnene } \\
\text { (vacuum) }\end{array}$ & $\begin{array}{l}\text { Volume } \\
\text { toluene }\end{array}$ & $\begin{array}{c}D: 0 \\
\text { toluene }\end{array}$ & $\begin{array}{c}\text { Weight } \\
\text { levulose } \\
\text { (vacuum) }\end{array}$ & $\begin{array}{l}\text { Weight } \\
\text { toluene } \\
\text { (vacuum) }\end{array}$ & $\begin{array}{c}\text { Total } \\
\text { volume }\end{array}$ & $\begin{array}{l}\text { Volume } \\
\text { toluene }\end{array}$ & $\begin{array}{l}\text { Volume } \\
\text { levulose }\end{array}$ & $\begin{array}{c}D^{20} \\
\text { levulose }\end{array}$ \\
\hline $\begin{array}{l}g \\
18.0143 \\
18.0330 \\
18.0075\end{array}$ & $\begin{array}{c}m \\
20.794 \\
20.814 \\
20.783\end{array}$ & $\begin{array}{r}0.86632 \\
.86639 \\
.86645\end{array}$ & \begin{tabular}{r}
\multicolumn{1}{c}{$g$} \\
10. 7459 \\
3.8529 \\
6.7969
\end{tabular} & $\begin{array}{c}g \\
\text { 12. } 1948 \\
15.9482 \\
14.3284\end{array}$ & $\begin{array}{c}m l \\
20.801 \\
20.820 \\
20.790\end{array}$ & $\begin{array}{c}m l \\
14.075 \\
18.408 \\
16.538\end{array}$ & $\begin{array}{l}m l . \\
6.726 \\
2.412 \\
4.252\end{array}$ & $\begin{array}{l}1.5977 \\
1.5974 \\
1.5984\end{array}$ \\
\hline \multicolumn{2}{|c|}{ Average } & .86639 & & & & & & 1.598 \\
\hline
\end{tabular}

\section{REFRACTIVE INDICES OF LEVULOSE SOLUTIONS}

The convenience and precision of the modern refractometer make it desirable that this instrument become available for the determination of levulose concentrations. For the measurements recorded below, three instruments were employed, namely, a Zeiss immersion refractometer, a Valentine refractometer of the Abbe type, which permitted an estimation of the fifth decimal of index, and for the highest concentrations an Abbe instrument, permitting an estimate of the fourth decimal.

The indices of solutions ranging from zero to about 20 per cent were measured by means of a Zeiss immersion refractometer. This instrument had previously been carefully calibrated at five points by L. W. Tilton, of this bureau, by means of salt solutions whose indices were determined on a precision spectrometer. It was our privilege to consult Mr. Tilton frequently during the course of these experiments and his assistance is gratefully acknowledged.

The measurements were made in a large thermostat containing about 200 liters in which temperature was maintained within $0.01^{\circ}$ of constancy. Preliminary experiments showed that unless the temperature of the room was closely the same as that of the bath the flow of heat through the barrel of the instrument affected slightly the temperature of the small body of solution under observation. It was deemed necessary then to control the temperature of the whole refractometer as far as feasible. For the final readings the levulose solution was contained in the metal cup provided with the refractometer. The instrument itself was inserted in a large glass tube $77 \mathrm{~mm}$ in diameter and $28 \mathrm{~cm}$ long containing enough water to immerse the metal cup. The glass tube was immersed in the water of the large thermostat nearly to its upper rim and the mouth was stuffed with cotton cloth. Thermometers placed in the thermostat, in the water surrounding the cup, and in the air about the barrel of the refractometer showed essentially identical temperatures. Under these favorable conditions of temperature regulation the line of total reflection was exceedingly sharp and permitted a precision of setting within 0.1 or 0.2 of a drumhead division, or 0.01 or 0.02 of a scale division.

The instrument was illuminated by a frosted lamp placed in a large test tube immersed in the water of the thermostat, the light being reflected at the proper angle by a submerged mirror.

Concentrations of levulose were selected to coincide with the calibrated points on the scale. Before or after each determination, readings were made with distilled water. Throughout the whole 
series this "zero point" remained constant at $14.42 \pm 0.01$ at $20.00^{\circ}$ C. All readings were corrected to correspond to a reading of 14.50 at $20^{\circ} \mathrm{C}$. or 13.25 at $25^{\circ} \mathrm{C}$. for distilled water as defined by the arbitrary scale of the instrument. These readings are equivalent to indices of 1.33300 at $20.00^{\circ}$ and of 1.33252 at $25^{\circ}$.

The arbitrary scale readings were translated into indices of refraction by means of the table of equivalents supplied by the manufacturer. Since the scale of the instrument had been calibrated by measurement of solutions whose indices were known, and since the instrument corrections were small, the indices of levulose solutions here presented are probably closely equivalent to absolute measurements, although admittedly they do not have the validity of measurements made with a spectrometer. It is the purpose of this bureau to undertake absolute measurements at some future time.

While the precision of setting of the line of total reflection was usually 0.01 or 0.02 scale division, corresponding to some units in the sixth decimal of refractive index, confidence is placed only in 0.1 scale division or 3 or 4 units in the fifth decimal. There are apparently some factors beside precision of setting which are as yet imperfectly controlled.

Great caution must be exercised in the use of the arbitrary scale. The data presented here refer solely to readings made on instruments graduated according to the scale as originally proposed by Pulfrich. ${ }^{9}$ On this scale, 14.5 is equivalent to $1.33300 ; 50.0$ to 1.34650 ; and 100.0 to 1.36464. If instruments are used which do not conform to the original system, the arbitrary scale readings must first be converted to refractive indices before reference is made to the index tables presented below.

In Table $7(a)$ are presented the observed data at $20^{\circ}$ and $25^{\circ} \mathrm{C}$. Sylvia M. Goergen has computed by the method of least squares interpolation formulas (6) and (7) which are valid between 0 and 20 per cent levulose, and has ascertained the agreement between the calculated and observed data.

$$
\begin{aligned}
& n_{D}^{20}=1.33300+0.0014159 p+0.00000491 p^{2} \\
& n_{D}^{25}=1.33252+0.0014059 p+0.00000487 p^{2}
\end{aligned}
$$

The indices and scale readings at integral percentage concentrations are given in Table 20, page 438 .

The measurements for the range 18 to 86 per cent levulose (Table $7(b)$ ) were made with the Valentine refractometer of the Abbe type in a thermostated room maintained at $20^{\circ} \mathrm{C}$. The temperature of the prisms was further controlled by water circulated from a thermostat. The readings at $25^{\circ}$ were made in a laboratory whose temperature was uncontrolled, but the circulating water was carefully controlled at approximately $25^{\circ} \mathrm{C}$. Temperature corrections resulting from deviations of the circulation water from the standard temperatures were small and could be applied with but little uncertainty.

Indices for the range 86 to 89 per cent (Table $7(c)$ ) were measured with the Abbe refractometer. Both of these Abbe type refractometers had been calibrated at several scale points. 
All solutions were made up by weighing the pure dry levulose and adding the calculated amount of water. The supersaturated solutions were prepared by dissolving the sugar in hot water, but the final weighing was not made until the resulting solutions were cooled. All percentages are expressed in terms of weights in air with brass weights.

Least square adjustment yielded formulas

$$
\begin{aligned}
& n_{D}^{20}=1.33344+0.0013625 p+0.000006645 p^{2} \\
& n_{D}^{25}=1.33312+0.0013415 p+0.000006762 p^{2}
\end{aligned}
$$

which are valid between 20 and 63 per cent levulose, and

$$
\begin{aligned}
& n_{D}^{20}=1.33377+0.0013570 p+0.000006680 p^{2} \\
& n_{D}^{25}=1.33345+0.0013360 p+0.000006800 p^{2}
\end{aligned}
$$

valid between 63 and 90 per cent levulose. The experimental and calculated data are included in Table 7 and the computed indices

\begin{tabular}{|c|c|c|c|c|c|c|c|c|}
\hline $\begin{array}{l}\text { Weight } \\
\text { levulose, } \\
\text { air, brass } \\
\text { weights }\end{array}$ & $\begin{array}{l}\text { Weight } \\
\text { solution, } \\
\text { air, brass } \\
\text { weights }\end{array}$ & $\begin{array}{l}\text { Concen- } \\
\text { tration of } \\
\text { levulose }\end{array}$ & $\begin{array}{c}\text { Zeiss im- } \\
\text { mersion } \\
\text { scale } \\
\text { reading } \\
t=20.0^{\circ}\end{array}$ & $n_{D}^{20}$ & $\begin{array}{l}\text { Deviation } \\
\text { from } \\
\text { formula (6) }\end{array}$ & $\begin{array}{c}\text { Zeiss im- } \\
\text { mersion } \\
\text { scale } \\
\text { reading } \\
t=25.0^{\circ}\end{array}$ & $n_{D}^{25}$ & $\begin{array}{l}\text { Deviation } \\
\text { from } \\
\text { formula (7) }\end{array}$ \\
\hline$g$ & $g$ & $\begin{array}{c}\text { Per cent } \\
0\end{array}$ & 14.50 & 1.33300 & 0 & 13.25 & 1.33252 & \\
\hline $\begin{array}{l}0.4381 \\
.8312 \\
.7440\end{array}$ & $\begin{array}{r}9.0108 \\
16.7541 \\
8.8401\end{array}$ & $\begin{array}{l}4.862 \\
4.961 \\
8.416\end{array}$ & $\begin{array}{l}14.77 \\
32.77 \\
46.76\end{array}$ & $\begin{array}{l}1.34001 \\
1.34016 \\
1.34528\end{array}$ & $\begin{array}{l}0 \\
0 \\
+.00002\end{array}$ & 31.39 & $\begin{array}{l}\text { 1. } 33202 \\
\text { 1. }\end{array}$ & +.00002 \\
\hline $\begin{array}{l}1.5447 \\
1.9047 \\
1.2075 \\
1.6200\end{array}$ & $\begin{array}{r}17.9232 \\
16.0668 \\
7.9699 \\
8.4827\end{array}$ & $\begin{array}{r}8.618 \\
11.855 \\
15.151 \\
19.098\end{array}$ & $\begin{array}{l}47.60 \\
60.60 \\
74.66 \\
92.11\end{array}$ & $\begin{array}{l}1.34560 \\
1.35043 \\
1.35557 \\
1.36185\end{array}$ & $\begin{array}{l}0 \\
-.00005 \\
-.00001 \\
+.00002\end{array}$ & $\begin{array}{l}46.01 \\
59.02 \\
72.92 \\
90.16\end{array}$ & $\begin{array}{l}1.34500 \\
1.34985 \\
1.35494 \\
1.36115\end{array}$ & $\frac{0}{-0} .00002$ \\
\hline
\end{tabular}
for 1 per cent intervals in Table 20, page 438 .

TABLE 7.-Refractive indices of levulose solutions

(a) MEASURED ON IMMERSION REFRACTOMETER

1 The arbitrary scale units employed here conform solely to the system as originally proposed for the immersion refractometer; thus, for example, $14.50=n_{D} 1.33300 ; 100.0=1.36464$. (Pulfrich, Zeit. f. angew Chemie, p. 1186, 1899.)

2 Derived from table of equivalents which convert arbitrary scale readings into indices of refraction. 
TABLE 7.-Refractive indices of levulose solutions-Continued

(b) MEASURED ON VALENTINE-ABBE REFRACTOMETER

\begin{tabular}{|c|c|c|c|c|c|c|}
\hline $\begin{array}{l}\text { Weight } \\
\text { levulose, } \\
\text { air, brass } \\
\text { weights }\end{array}$ & $\begin{array}{l}\text { Weight } \\
\text { solution, } \\
\text { air, brass } \\
\text { weights }\end{array}$ & $\begin{array}{l}\text { Concen- } \\
\text { tration of } \\
\text { levulose }\end{array}$ & $\begin{array}{c}n_{D}^{20} \\
\text { observed }\end{array}$ & $\begin{array}{l}\text { Deviation } \\
\text { from } \\
\text { formula (8) }\end{array}$ & $\begin{array}{c}n_{D}^{25} \\
\text { observed }\end{array}$ & $\begin{array}{c}\text { Deviation } \\
\text { from } \\
\text { formula (9) }\end{array}$ \\
\hline \multirow{2}{*}{$\begin{array}{r}g \\
1.0850 \\
1.0688 \\
1.1919 \\
1.4402 \\
17.1008\end{array}$} & \multirow{2}{*}{$\begin{array}{r}g \\
5.7274 \\
4.6561 \\
4.4228 \\
4.6590 \\
54.8660\end{array}$} & \multirow{2}{*}{$\begin{array}{c}\text { Per cent } \\
18.944 \\
22.955 \\
26.948 \\
30.912 \\
31.168\end{array}$} & \multirow{2}{*}{$\begin{array}{l}\text { 1. } 36157 \\
\text { 1. } 36822 \\
1.37503 \\
1.38197 \\
1.38239\end{array}$} & \multirow{2}{*}{$\begin{array}{r}-0.00006 \\
0 \\
+.00005 \\
+.00006 \\
+.00003\end{array}$} & $\begin{array}{l}1.36094 \\
1.36748\end{array}$ & $+_{0}^{0.00001}$ \\
\hline & & & & & $\begin{array}{l}1.38104 \\
1.38162\end{array}$ & $\begin{array}{l}+.00001 \\
+.00012\end{array}$ \\
\hline 44. 7960 & 143.1180 & 31.300 & 1.38259 & -.00001 & & \\
\hline $\begin{array}{r}2.6925 \\
23.4678\end{array}$ & $\begin{array}{r}6.5822 \\
57.2366\end{array}$ & $\begin{array}{l}40.906 \\
41.001\end{array}$ & $\begin{array}{l}1.40035 \\
1.40046\end{array}$ & $\begin{array}{r}+.00005 \\
-.00002\end{array}$ & $\begin{array}{l}1.39932 \\
1.39950\end{array}$ & $\begin{array}{l}0 \\
+.00001\end{array}$ \\
\hline 61.3617 & 149.3230 & 41.093 & 1. 40059 & -.00006 & 1. 39958 & -.00008 \\
\hline 15. 6291 & $\begin{array}{r}31.1260 \\
\end{array}$ & 50. 212 & 1.41856 & -.00005 & 1.41758 & +.00005 \\
\hline $\begin{array}{l}18.7291 \\
98.3700\end{array}$ & $\begin{array}{r}32.2222 \\
162.6270\end{array}$ & $\begin{array}{l}58.125 \\
60.488\end{array}$ & $\begin{array}{l}1.43510 \\
1.44013\end{array}$ & $\begin{array}{r}.00001 \\
+.00004 \\
-.000\end{array}$ & $\begin{array}{l}1.43398 \\
1.43894\end{array}$ & $\begin{array}{r}+.00003 \\
-.00007\end{array}$ \\
\hline $\begin{array}{l}\text { Weight } \\
\text { levulose, } \\
\text { air, brass } \\
\text { weights }\end{array}$ & $\begin{array}{l}\text { Weight } \\
\text { solution, } \\
\text { air, brass } \\
\text { weights }\end{array}$ & $\begin{array}{l}\text { Concen- } \\
\text { tration of } \\
\text { levulose }\end{array}$ & $\begin{array}{c}n_{D}^{20} \\
\text { observed }\end{array}$ & $\begin{array}{c}\text { Deviation } \\
\text { from } \\
\text { formula (10) }\end{array}$ & $\begin{array}{c}n_{D}^{25} \\
\text { observed }\end{array}$ & $\begin{array}{l}\text { Deviation } \\
\text { from } \\
\text { formula (11) }\end{array}$ \\
\hline$g$ & & Per cent & & & & \\
\hline $\begin{array}{r}23.4191 \\
5.8569\end{array}$ & $\begin{array}{r}33.8590 \\
7.7837\end{array}$ & $\begin{array}{l}69.166 \\
75.246\end{array}$ & $\begin{array}{l}1.45964 \\
1.47383\end{array}$ & $\begin{array}{r}+0.00006 \\
+.00013\end{array}$ & $\begin{array}{l}1.45845 \\
1.47261\end{array}$ & $\begin{array}{r}-.00005 \\
+.00009\end{array}$ \\
\hline 8.5520 & 11. 2766 & 75. 838 & 1. 47524 & +.00014 & 1. 47399 & +.00008 \\
\hline $\begin{array}{l}4.8635 \\
4.8365\end{array}$ & $\begin{array}{l}\text { 6. } 1826 \\
5.8752\end{array}$ & $\begin{array}{l}\text { 78. } 664 \\
82.321\end{array}$ & $\begin{array}{l}1.48188 \\
1.49062\end{array}$ & $\begin{array}{l}+.00003 \\
-.00012\end{array}$ & $\begin{array}{l}1.48046 \\
1.48945\end{array}$ & $\begin{array}{r}-.00015 \\
+.00001\end{array}$ \\
\hline $\begin{array}{r}12.0706 \\
4.6539\end{array}$ & 14. 6504 & 82. 390 & 1. 49093 & $\begin{array}{r}.00002 \\
+.0016\end{array}$ & 1. 48967 & +.00006 \\
\hline 4.6539 & & & 1.49954 & & 1.49823 & -.00001 \\
\hline
\end{tabular}

(c) MEASURED ON ABBE REFRACTOMETER

\begin{tabular}{|r|r|r|r|r|r|r|}
\hline 5.5476 & 6.3893 & 86.826 & 1.5019 & 0 & & \\
10.2809 & 11.6725 & 88.073 & 1.5052 & +.0001 & 1.5038 & +0.0001 \\
10.7568 & 12.1401 & 88.601 & 1.5065 & +.0001 & 1.5051 & +.0001 \\
10.8767 & 12.2217 & 88.991 & 1.5073 & -.0001 & 1.5060 & 0 \\
10.9897 & 12.3035 & 89.321 & 1.5082 & -.0001 & 1.5069 & +.0001 \\
\hline
\end{tabular}

\section{SACCHARIMETRIC NORMAL WEIGHT OF LEVULOSE}

\section{MEASUREMENTS OF SACCHARIMETRIC ROTATIONS}

No measurements have previously been published of the rotatory power of levulose in terms of the white light of the quartz-wedge saccharimeter. Since this instrument is the most convenient means of carrying out polariscopic analysis, the experiments here described were made to determine the normal weight of crystalline levulose $\left(W o\right.$ ) which in $100 \mathrm{ml}$ of solution reads $-100^{\circ} \mathrm{S}$. and the normal weights $(W)$ of aqueous solutions which, when diluted to $100 \mathrm{ml}$, show rotations in negative sugar degrees equal to their respective percentage concentrations. The distinction between $W_{0}$ and the variable weights $W$ is necessarily introduced because the rotation of levulose does not vary strictly linearly with concentration. Let it be noted that in the following discussion Wo alone represents the normal weight of pure crystalline levulose, while the W's represent 
weights of solution of pure levulose in water. The latter will yield polariscopic readings equal to their percentage concentrations.

In the absence of direct measurements it has previously been customary to assume that the normal weights of sucrose and levulose were in the inverse ratio of their respective specific rotations. This involves the assumption that the rotatory dispersions of levulose and sucrose are identical. Since the latter assumption has not been verified experimentally, and since the specific rotation itself is known with little certainty, any computed value of the normal weight is but an approximation.

The present measurements were made with a Bates type Fric saccharimeter which had been used in previous similar investigations. Its negative scale was calibrated against the quartz plates which serve as primary standards of this bureau, and whose absolute rotations have been measured many times on a high precision polarimeter. The sugar values of these plates were expressed in terms of the normal quartz plate as measured by Bates and Jackson. ${ }^{10}$ According to this standardization the normal quartz plate rotates $40.690^{\circ}$ for $\lambda=5,461 \mathrm{~A}$, and $34.620^{\circ}$ for $\lambda=5,892.5 \mathrm{~A}$ at $20^{\circ} \mathrm{C}$.

The solutions whose rotations were measured were those whose concentrations and densimetric data are tabulated in Table 2. The readings were made in water-jacketed polariscope tubes whose lengths were accurately known. Temperatures were observed frequently by means of calibrated thermometers and were, in general, constant for long periods of time within $0.02^{\circ}$ to $0.05^{\circ} \mathrm{C}$. The saccharimeter was illuminated by a 100 -watt lamp, the light from which passed through a $15 \mathrm{~mm}$ column of 6 per cent potassium dichromate before entering the instrument. Before observation the solutions usually had stood for at least two hours, and therefore, mutarotation was in every instance complete. ${ }^{11}$

All temperature corrections were reduced to a minimum by careful temperature control. The corrections for variations in temperature of the quartz wedges were calculated by assuming a temperature coefficient of quartz of $0.000144 .^{12}$

In order to apply proper temperature corrections for the levulose solutions, rotations were observed at $20^{\circ}$ and at $25^{\circ} \mathrm{C}$. Since the concentrations had also been previously determined at both temperatures, this procedure served the purpose of determining the normal weights at both temperatures as well as providing a reliable means of correcting for small deviations from the two standard temperatures.

For computing the rotations, all operations and apparatus, including quartz wedges, were adjusted or corrected to the two respective standard temperatures.

The observations are recorded in Tables 8 and 9 . The normal weights at the respective concentrations were computed by dividing the number of grams of levulose (c) in $100 \mathrm{ml} \times 100$ by the observed rotation.

$$
\frac{100 \times c}{\text { Obs. pol. }}=W
$$

10 B. S. Sci. Paper No. 268, vol. 13, p. 67, 1916.

11 According to Hudson and Yanovsky (B. S. Sci. Papers No. 533, vol. 21, p. 271, 1926) the mutarotation velocity constant is 0.082 at $20^{\circ} \mathrm{C}$.

12 Bates, Bull. B. S., vol. 2, p. 245, 1906. 
These values vary with concentration in the same manner as the specific rotation. The observed normal weights were correlated with the concentrations by the method of least squares, yielding the formulas

$$
\begin{aligned}
& W_{t=20}=18.803-0.01801 c-0.000191 c^{2} \\
& W_{t=25}=19.446-0.02061 c-0.000141 c^{2}
\end{aligned}
$$

in which $c$ is the number of grams of levulose in $100 \mathrm{ml}$ weighed in air with brass weights.

From the adjusted normal weights the adjusted polarizations were computed by dividing each concentration by the respective adjusted normal weight. The deviations of the observed polariscopic readings from the computed readings are shown in columns 6 of Tables 8 and 9 .

The normal weight of the normal solution or the concentration of levulose required to read exactly $-100^{\circ} \mathrm{S}$. was calculated from formulas (13) and (14) by imposing the condition that $c=W_{0} .^{13}$ Upon solution of the resulting equations we obtain $18.4067 \mathrm{~g}$ for the normal weight $\left(W_{0}\right)$ of levulose at $20^{\circ}$, and $19.0030 \mathrm{~g}$ at $25^{\circ} \mathrm{C}$. We shall accept the values 18.407 and 19.003 , respectively, weighed in air with brass weights.

\begin{tabular}{|c|c|c|c|c|c|c|c|}
\hline $\begin{array}{l}\text { Levulose } \\
\text { (vacuum) }\end{array}$ & $\begin{array}{l}\text { Weight } \\
\text { levulose } \\
\text { in } 100 \mathrm{ml} \\
\text { (air, brass } \\
\text { weights) }\end{array}$ & $D_{4}^{20}$ & $\begin{array}{c}\text { Observed } \\
\text { polariza- } \\
\text { tion at } \\
20^{\circ} \mathrm{C} \text {. } \\
\times(-1)\end{array}$ & $\begin{array}{l}\text { Calcu- } \\
\text { lated } \\
\text { polariza- } \\
\text { tion } \\
\times(-1)\end{array}$ & $\begin{array}{l}\text { Devia- } \\
\text { tion obs.- } \\
\text { calc. po- } \\
\text { larization } \\
\times(-1)\end{array}$ & $\begin{array}{c}\text { Observed } \\
\text { normal } \\
\text { weight }\end{array}$ & $\begin{array}{c}\text { Calcu- } \\
\text { lated } \\
\text { normal } \\
\text { weight } \\
\text { formula } \\
\text { (13) }\end{array}$ \\
\hline $\begin{array}{r}\text { Per cent } \\
5.5909 \\
8.9977 \\
9.5341 \\
13.4846 \\
15.3442\end{array}$ & $\begin{array}{r}g \\
5.7018 \\
9.3017 \\
9.8771 \\
14.1916 \\
16.2737\end{array}$ & $\begin{array}{l}1.02041 \\
1.03437 \\
1.03656 \\
1.05318 \\
1.06119\end{array}$ & $\begin{array}{c}{ }^{\circ} S \\
30.49 \\
49.98 \\
53.11 \\
76.63 \\
88.11\end{array}$ & $\begin{array}{c}\circ \mathrm{S} \\
30.50 \\
49.96 \\
53.09 \\
76.59 \\
88.16\end{array}$ & $\begin{array}{l}\circ \mathrm{S} \\
-0.01 \\
+.02 \\
+.02 \\
+.04 \\
-.05\end{array}$ & $\begin{array}{l}g \\
18.701 \\
18.611 \\
18.597 \\
18.519 \\
18.471\end{array}$ & $\begin{array}{c}g \\
18.694 \\
18.619 \\
18.606 \\
18.509 \\
18.459\end{array}$ \\
\hline $\begin{array}{c}17.222 \\
17.229 \\
17.289 \\
17.952\end{array}$ & $\begin{array}{l}18.4063 \\
19.4146 \\
18.4821 \\
18.5672 \\
19.2444\end{array}$ & $\begin{array}{r}1.06937 \\
1.06944 \\
1.06965 \\
1.07259\end{array}$ & $\begin{array}{l}100.02 \\
100.01 \\
100.44 \\
100.87 \\
104.66\end{array}$ & $\begin{array}{r}100.00 \\
99.96 \\
100.46 \\
100.89 \\
10467\end{array}$ & $\begin{array}{l}+.02 \\
+.05 \\
-.02 \\
-.02 \\
-.01\end{array}$ & $\begin{array}{l}18.404 \\
18.397 \\
18.400 \\
18.406 \\
18.388\end{array}$ & $\begin{array}{l}18.407 \\
18.406 \\
18.405 \\
18.403 \\
18.385\end{array}$ \\
\hline
\end{tabular}

TABLE 8.-Saccharimetric rotations of levulose solutions at $20^{\circ} \mathrm{C}$.

\begin{tabular}{|c|c|c|c|c|c|c|c|}
\hline $\begin{array}{l}\text { Levulose } \\
\text { (vacuum) }\end{array}$ & $\begin{array}{l}\text { Weight } \\
\text { levulose } \\
\text { in } 100 \mathrm{ml} \\
\text { (air, brass } \\
\text { weights) }\end{array}$ & $D_{4}^{23}$ & $\begin{array}{c}\text { Observed } \\
\text { polariza- } \\
\text { tion at } \\
25^{\circ} \mathrm{C} \\
\times(-1)\end{array}$ & $\begin{array}{l}\text { Calcu- } \\
\text { lated } \\
\text { polari- } \\
\text { zation } \\
\times(-1)\end{array}$ & $\begin{array}{l}\text { Devia- } \\
\text { tion } \\
\text { obs.- } \\
\text { calc. po- } \\
\text { lariza- } \\
\text { tion } \\
\times(-1)\end{array}$ & $\begin{array}{c}\text { Observed } \\
\text { normal } \\
\text { weight }\end{array}$ & $\begin{array}{c}\text { Calcu- } \\
\text { lated } \\
\text { normal } \\
\text { weight } \\
\text { formula } \\
\text { (14) }\end{array}$ \\
\hline $\begin{array}{r}\text { Per cent } \\
5.5909 \\
8.9977 \\
13.4846 \\
15.3442\end{array}$ & $\begin{array}{r}g \\
5.6944 \\
9.2880 \\
14.1709 \\
16.2479\end{array}$ & $\begin{array}{l}1.01909 \\
1.03285 \\
1.05165 \\
1.05949\end{array}$ & $\begin{array}{l}\circ \mathrm{S} . \\
29.47 \\
48.28 \\
74.12 \\
85.18\end{array}$ & $\begin{array}{l}{ }^{\circ} S . \\
29.47 \\
48.27 \\
74.09 \\
85.19\end{array}$ & $\begin{array}{l}{ }^{\circ} S . \\
0.00 \\
+.01 \\
+.03 \\
-.01\end{array}$ & $\begin{array}{c}g \\
19.321 \\
19.249 \\
19.118 \\
19.075\end{array}$ & $\begin{array}{c}g \\
19.324 \\
19.242 \\
19.125 \\
19.074\end{array}$ \\
\hline $\begin{array}{l}17.2218 \\
17.229 \\
17.289 \\
17.952\end{array}$ & $\begin{array}{l}18.3758 \\
18.3834 \\
18.4520 \\
19.2104\end{array}$ & $\begin{array}{r}1.06759 \\
1.06762 \\
1.06790\end{array}$ & $\begin{array}{r}96.56 \\
96.69 \\
97.06 \\
101.12\end{array}$ & $\begin{array}{r}96.62 \\
96.66 \\
97.03 \\
101.12\end{array}$ & $\begin{array}{r}-.06 \\
+.03 \\
+.03 \\
.00\end{array}$ & $\begin{array}{l}19.031 \\
19.014 \\
19.012 \\
18.998\end{array}$ & $\begin{array}{l}19.019 \\
19.019 \\
19.017 \\
18.998\end{array}$ \\
\hline
\end{tabular}

TABLE 9.-Saccharimetric rotations of levulose solutions at $25^{\circ} \mathrm{C}$.

13 This yields the equations

$$
c_{t=20}=18.803-0.01801 c-0.000191 c^{2}
$$

$c_{\{-2 s}=19.446-0.02061 c-0.000141 c^{2}$

The $c^{2}$ terms were determined numerically with sufficient accuracy by interpolation between two calculated values for solutions approximately normal. 
If the polarization were to indicate directly the percentage of levulose in the sample taken for analysis, it would be necessary to take a different normal weight for each concentration. It is more convenient to employ a constant normal weight and apply corrections for the deviations of rotation from constant proportionality. To determine these corrections, formulas (13) and (14) were solved for each integral value of $c$ from 1 to $20 \mathrm{~g}$ yielding the respective normal weights. Each value of $c$ multiplied by 100 and divided by its respective normal weight yields a numerical value equal to the actual rotation for each concentration. But each value of $c$ divided by the constant normal weights 18.407 and 19.003 yields the percentage of levulose in the sample taken for analysis. The deviation of the actual rotation from the percentage of levulose is a measure of the correction to be applied to the polarization in order to give the true percentage composition of the sample. These corrections are given in Table 21, page 439.

\section{CHANGE OF POLARIZATION OF LEVULOSE BETWEEN WIDELY SEPARATED TEMPERATURES}

The high temperature coefficient of the rotatory power of levulose suggests that polariscopic readings at widely separated temperatures may serve as a measure of the concentration of the sugar. ${ }^{14}$ The measurement is in a high degree dependent upon the efficiency of the apparatus used for temperature control. The measurements reported below were made in water-jacketed continuous polariscope tubes, $400 \mathrm{~mm}$ in length, constructed of Monel metal. Within the water jacket was placed a spiral baffle which imparted a rotary motion to the water stream, thus greatly increasing the velocity of water over the surface of the tube. We acknowledge gratefully the assistance of M. J. Proffitt and J. A. Bogan in the designing of these tubes.

Water was supplied by centrifugal pumps operating in thermostats held at the high and low temperatures, respectively. The temperatures of polarization were observed by means of thermometers placed in the circulating water immediately before its entrance into and after its emergence from the water jacket. In general, the water stream was so abundant and rapid that the two thermometers showed closely agreeing temperatures. The mean of the readings of the two thermometers was assumed to be the true temperature of the solution. The stem corrections of the thermometers were carefully calculated for the high temperature observation.

The observations for concentrations of levulose from 3 to $9 \mathrm{~g}$ in $100 \mathrm{ml}$ were made in a $400 \mathrm{~mm}$ Bates-Fric saccharimeter. The remaining measurements were made in a Schmidt and Haensch 600 $\mathrm{mm}$ instrument with a quartz plate of $+100.05^{\circ}$ sugar value placed in series with the tubes.

Corrections were made for the deviation of the temperature of the quartz wedges and the quartz plate from the standard temperatures. We suggest as a matter of definition that the high temperature polarization be measured with the quartz wedges at the same temperature as that of the low temperature measurement. The expansion of the solution at the high temperature was corrected for by using the expansion coefficients given in Table 5.

14 For a review of this subject see Browne's Handbook of Sugar Analysis, p. 297, 1912, John Wiley \& Sons, Now York. 
The experimental data shown in Table 10 indicate that between room temperature and about $70^{\circ}$ to $75^{\circ}$ C. $1 \mathrm{~g}$ of levulose in $100 \mathrm{ml}$ changes $0.0344^{\circ} \mathrm{S}$. for each degree change in temperature . Contrary to Vosburgh's ${ }^{15}$ conclusions, our data show no systematic deviation of the coefficient with concentration of sugar. The measurements indicate that levulose can be determined by this method with a mean precision of about one-third of 1 per cent of the quantity measured. This degree of precision has, however, been secured only by great attention to detail and by averaging a considerable number of observations.

TABLE 10.-Change of polarization of levulose between wide temperature intervals

\begin{tabular}{|c|c|c|c|c|c|c|c|c|c|c|}
\hline $\begin{array}{l}\text { Weight } \\
\text { levulose } \\
\text { in } 100 \mathrm{ml} \\
\text { at } 20^{\circ} \mathrm{C} \text {. }\end{array}$ & $\begin{array}{l}\text { Num- } \\
\text { ber of } \\
\text { obser- } \\
\text { vations }\end{array}$ & $\begin{array}{c}\text { Polariza- } \\
\text { tion } 1 \text { at } \\
t^{\circ}{ }_{1} \mathrm{C} .\end{array}$ & $\begin{array}{c}\text { Temper- } \\
\text { ature } \\
t^{\circ}{ }_{1} \mathrm{C} .\end{array}$ & $\begin{array}{c}\text { Polariza- } \\
\text { tion }{ }^{2} \text { at } \\
t_{2}\end{array}$ & $\begin{array}{l}\text { Temper- } \\
\text { ature } \\
t_{2}{ }^{\circ} \mathrm{C} .\end{array}$ & $\Delta P$ & $\Delta T$ & $\frac{\Delta P}{\Delta T \times g}$ & $\begin{array}{l}\text { Levulose } \\
\text { calculated }\end{array}$ & Error \\
\hline $\begin{array}{r}{ }^{g} \\
3.000 \\
6.000 \\
9.000 \\
12.000 \\
15.000 \\
18.000\end{array}$ & $\begin{array}{l}7 \\
8 \\
6 \\
3 \\
3 \\
3 \\
3\end{array}$ & $\begin{array}{c}{ }^{\circ} \mathrm{S} . \\
15.94 \\
32.21 \\
48.46 \\
62.90 \\
78.78 \\
95.02\end{array}$ & $\begin{array}{l}20.10 \\
19.59 \\
19.70 \\
24.13 \\
24.13 \\
24.00\end{array}$ & $\begin{array}{c}{ }^{\circ} S . \\
10.84 \\
21.56 \\
32.39 \\
41.77 \\
52.57 \\
63.12\end{array}$ & $\begin{array}{l}69.54 \\
70.95 \\
71.78 \\
74.83 \\
75.16 \\
75.70\end{array}$ & $\begin{array}{r}{ }^{\circ} \mathrm{S} . \\
5.10 \\
10.65 \\
16.07 \\
21.13 \\
26.21 \\
31.90\end{array}$ & $\begin{array}{l}{ }^{\circ} \mathrm{C} \text {. } \\
49.44 \\
51.36 \\
52.08 \\
50.70 \\
51.03 \\
51.70\end{array}$ & $\begin{array}{r}0.03439 \\
.03456 \\
.03428 \\
.03473 \\
.03424 \\
.03423\end{array}$ & $\begin{array}{r}g \\
2.998 \\
6.026 \\
8.967 \\
12.111 \\
14.927 \\
17.934\end{array}$ & $\begin{array}{c}\text { Per cent } \\
-0.07 \\
+.43 \\
-.41 \\
+.93 \\
-.52 \\
-.35\end{array}$ \\
\hline Average & & & & & & & & .03441 & & .35 \\
\hline
\end{tabular}

1 Polarizations are corrected for length of tube and temperature of quartz wedges.

\section{COPPER REDUCTION METHODS FOR TOTAL REDUCING SUGAR}

\section{METHOD OF MUNSON AND WALKER}

The method of Munson and Walker ${ }^{16}$ is well adapted to the determination of total reducing sugar over a wide range of concentrations. In the articles in which the method was originally described the authors gave the copper equivalents for dextrose and invert sugar but no equivalents for levulose. In order that this widely employed method might become available for sugar mixtures having a high ratio of levulose, we have made analyses of pure levulose for the purpose of determining the respective copper equivalents.

The details ${ }^{17}$ of the analyses were carried out rigorously in accordance with Munson and Walker's specifications, except that copper was determined by thiosulphate titration instead of by direct weighing of the copper precipitate. The titration method is less tedious and eliminates many of the uncertainties inherent in gravimetric analysis.

Immediately preceding the analysis of each levulose solution a similar analysis was conducted with a standard dextrose solution of such sugar content that both precipitated approximately the same weight of copper.

In Table 11 are shown the data obtained. Columns 2 and 3 show that the present experiments are in essential agreement with Munson and Walker's data on dextrose. Column 6 shows the weight of levulose (calculated from columns 4 and 5) which yields the same weight of copper (column 2) as the dextrose in column 1, and column 7 the ratio of weights of the sugars. These observed ratios were plotted against the weight of dextrose and from the smoothed curve the values in column 8 were read. The reciprocals of these values are given in column 11 .

\footnotetext{
is J. Am. Chem. Soc., vol. 42, p. 1696, 1920.

18 J. Am. Chem. Soc., vol. 28, p. 663, 1906; vol. 29, p. 541, 1907; vol. 34, p. 202, 1912.

${ }_{17}$ Quoted paragraphs are reprinted from the Report on Chemical Methods for Reducing Sugars, by R. F. Jackson, associate referee (J. Assoc. Official Agri. Chem., vol. 13, p. 199, 1930).
} 
From column 8 it is apparent that the reducing ratio is a function of the concentration of sugar. Evidently the practice of employing a single-valued ratio, regardless of concentration of sugar, is hazardous, unless it has been demonstrated that the ratio is constant.

In column 10 are the ratios of weights of invert sugar to dextrose computed from Munson and Walker's table. If it is assumed that the reducing power of a sugar mixture is an additive property of the constituents, the ratios of invert sugar to dextrose can be extrapolated to those of levulose to dextrose, as is done in column 9. A comparison of these extrapolated with the experimental ratios (column 8) reveals a serious discrepancy. Either the rule of mixtures is inaccurate or some error exists in the experimental data. Such error may occur either in the present data for levulose or in Munson and Walker's values for invert sugar.

TABLE 11.-Copper-reducing equivalents of dextrose and levulose by Munson and Walker's method

\begin{tabular}{|c|c|c|c|c|c|c|c|c|c|c|}
\hline $\begin{array}{c}\text { Weight } \\
\text { dextrose } \\
\text { taken }\end{array}$ & $\begin{array}{l}\text { Copper } \\
\text { found }\end{array}$ & $\begin{array}{c}\text { Copper } \\
\text { from } \\
\text { Munson } \\
\text { and } \\
\text { walker's } \\
\text { table }\end{array}$ & $\begin{array}{l}\text { Weight } \\
\text { levulose } \\
\text { táken }\end{array}$ & $\begin{array}{l}\text { Copper } \\
\text { found }\end{array}$ & $\begin{array}{c}\text { Weight } \\
\text { levulose } \\
\text { yielding } \\
\text { same } \\
\text { copper } \\
\text { as dex- } \\
\text { trose }\end{array}$ & $\begin{array}{l}\text { Ratio of } \\
\text { weights } \\
\text { of levu- } \\
\text { lose to } \\
\text { dextrose } \\
\text { observed }\end{array}$ & $\begin{array}{l}\text { Ratio } \\
\text { from } \\
\text { curve }\end{array}$ & $\begin{array}{c}\text { Munson } \\
\text { and } \\
\text { Walker's } \\
\text { table } \\
\text { extrapo- } \\
\text { lated to } \\
\text { levulose }\end{array}$ & $\begin{array}{l}\text { Ratio: } \\
\text { Weights } \\
\text { of invert } \\
\text { sugar to } \\
\text { dextrose } \\
\text { (Mun- } \\
\text { son and } \\
\text { Walker) }\end{array}$ & $\begin{array}{c}\text { Reduc- } \\
\text { ing } \\
\text { power } \\
\text { of levu- } \\
\text { lose } \\
\text { (recip- } \\
\text { rocal) of } \\
\text { col- } \\
\text { umn } 8\end{array}$ \\
\hline 1 & 2 & 3 & 4 & 5 & 6 & 7 & 8 & 9 & 10 & 11 \\
\hline $\begin{array}{c}m g \\
200 \\
200 \\
160 \\
120\end{array}$ & $\begin{array}{c}m g \\
375.1 \\
375.9 \\
307.0 \\
234.6\end{array}$ & $\begin{array}{c}m g \\
374.7 \\
374.7 \\
306.8 \\
235.4\end{array}$ & $\begin{array}{c}m g \\
213.1 \\
212.5 \\
170.5 \\
127.9\end{array}$ & $\begin{array}{c}m g \\
374.9 \\
374.1 \\
303.1 \\
231.0\end{array}$ & $\begin{array}{c}m g \\
213.1 \\
213.5 \\
172.7 \\
129.8\end{array}$ & $\begin{array}{l}\text { 1. } 066 \\
\text { 1. } 068 \\
\text { 1. } 079 \\
1.082\end{array}$ & $\begin{array}{l}1.067 \\
1.067 \\
1.075 \\
1.082\end{array}$ & $\begin{array}{l}1.056 \\
1.056 \\
1.060 \\
1.065\end{array}$ & $\begin{array}{l}1.028 \\
1.028 \\
1.030 \\
1.033\end{array}$ & $\begin{array}{r}0.937 \\
.937 \\
.930 \\
.924\end{array}$ \\
\hline $\begin{array}{l}100 \\
85.75 \\
64.31 \\
42.88\end{array}$ & $\begin{array}{r}197.7 \\
173.0 \\
129.9 \\
88.8\end{array}$ & $\begin{array}{r}198.3 \\
171.5 \\
130.2 \\
87.9\end{array}$ & $\begin{array}{c}106.6 \\
94.03 \\
70.52 \\
47.01\end{array}$ & $\begin{array}{r}194.4 \\
173.6 \\
130.8 \\
88.8\end{array}$ & $\begin{array}{r}108.4 \\
93.7 \\
70.0 \\
47.0\end{array}$ & $\begin{array}{l}\text { 1. } 084 \\
\text { 1. } 093 \\
1.089 \\
1.097\end{array}$ & $\begin{array}{l}1.086 \\
1.089 \\
1.093 \\
1.097\end{array}$ & $\begin{array}{l}1.067 \\
1.070 \\
1.074 \\
1.079\end{array}$ & $\begin{array}{l}1.034 \\
1.035 \\
1.037 \\
1.040\end{array}$ & $\begin{array}{l}.921 \\
.918 \\
.915 \\
.912\end{array}$ \\
\hline
\end{tabular}

\section{LANE AND EYNON'S VOLUMETRIC METHOD}

More expeditious and in most instances more precise than the gravimetric estimation of total reducing sugar is the volumetric method of Lane and Eynon. ${ }^{18}$ The method is described in the references cited and may be used without modification for the analysis of sugar mixtures containing levulose.

In their tabulation of empirical factors Lane and Eynon give the values for dextrose, invert sugar, and levulose. Inasmuch as levulose in natural products is almost invariably accompanied by dextrose in widely varying ratio, it has been found desirable to tabulate factors interpolated at 10 per cent intervals between pure dextrose and pure levulose. The interpolated factors are given in Table 22, page 439 .

The degree of precision attainable by this method is to a considerable extent dependent upon the skill and experience of the analyst. As a corollary of this fact individual procedure and possible variations in the composition of the reagents may cause variations in the standard factors. It is therefore important that the analyst standardize his own analysis by titrating pure solutions of the respective sugars, thus ascertaining the correction to be applied to Lane and Eynon's tables. The correction can be applied uniformly to the tabulated factors or to the burette reading.

\footnotetext{
19 J. Soc. Chem. Ind., vol. 42, p. 32, 1923. J. Assoc. Official Agri. Chem., vol. 9, p. 35, 1926.
} 
The calculation of levulose in a levulose-dextrose mixture determined by methods to be described below is necessarily based upon the uncorrected factors interpolated from Lane and Eynon's data. For this purpose it is necessary to compute what the burette reading would be if Lane and Eynon's factors applied to the titration without correction. The correction to the burette reading (for $25 \mathrm{ml}$ of Soxhlet reagent) is most conveniently determined by reference to the last three columns of Table 22, page 439.

The method of derivation of the quantities in this table is as follows: The factor correction found as described above by titrating $25 \mathrm{ml}$ of Soxhlet solution with a standard reducing sugar solution is

$$
c=\frac{S T}{100}-F
$$

in which $c=$ factor correction (difference between determined and tabulated factors), $S=\mathrm{mg}$ of reducing sugar per $100 \mathrm{ml}$ in solution taken, $T=$ observed titration, and $F=$ factor in Lane and Eynon's table corresponding to the observed titration. Lane and Eynon's factors satisfy the equation

$$
F_{\mathrm{o}}=\left(119.36+0.0471 T_{\mathrm{o}}+7.3 R\right)
$$

where $T_{\mathrm{o}}=$ titration in $\mathrm{ml}$ and $\mathrm{R}=$ ratio of levulose to total reducing sugar. The factor for any titration is

$$
F_{1}=119.36+0.0471 T_{1}+7.3 R+c
$$

where $c$ is the factor correction from equation (15). Since

$$
\begin{aligned}
& 100 \frac{F}{T}=\text { mg sugar } \\
& 100 \frac{F_{0}}{T_{0}}=100 \frac{F_{1}}{T_{1}}
\end{aligned}
$$

or

$$
\frac{119.36+0.0471 T_{0}+7.3 R}{T_{0}}=\frac{119.36+0.0471 T_{1}+7.3 R+c}{T_{1}}
$$

hence

$$
T_{1}-T_{0}=\frac{c T_{0}}{119.36+7.3 R}
$$

To solve equation (17) we must know the ratio of levulose to total reducing sugar as well as the titer and factor correction. Since in an unknown solution we do not know the ratio, $R$, and as $T_{0}$ will differ from $T_{1}$ by a very small amount, we can write as an approximation

$$
T_{1}-T_{0}=\frac{c T_{1}}{119.36+(7.3 \times 0.50)}=\frac{c T_{1}}{123.0}
$$

in which we assume that the ratio is 0.50 . The introduction of the approximation influences the value of the correction by a negligible amount, as the following example shows. 
Assume that the observed titration of a pure levulose solution was $25.00 \mathrm{ml}$ and the factor correction was 2.0 . From equation (18) we obtain

and

$$
T_{1}-T_{0}=0.41 \mathrm{ml}
$$

$$
T_{0}=24.59 \mathrm{ml}
$$

whereas from the more rigorous equation (17)

$$
T_{0}=24.61 \mathrm{ml}
$$

The difference between the two calculated values is within the experimental error of the titration.

The corrections in Table 22 were calculated from equation (18). It should be noted that when the factor correction, $c$, is positive, the titer correction is to be subtracted from the observed titer and vice versa.

\section{BIOURGE AND NYNS'S SELECTIVE DETERMINATION OF LEVULOSE}

\section{INTRODUCTORY}

In an effort to distinguish between levulose and dextrose by reduction methods Biourge ${ }^{19}$ made the important observation that at $50^{\circ} \mathrm{C}$. the quantity of copper reduced in Ost's reagent by levulose was ten times as great as that reduced by dextrose. At a later period Nyns ${ }^{20}$ elaborated the principle and determined the copper-levulose equivalents for a wide range of sugar concentrations. Notwithstanding Biourge's observation that dextrose had an appreciable reducing action under the conditions of the analysis, Nyns stated that neither dextrose nor other hexoses reduced even traces of copper. In a preliminary study of the method Jackson ${ }^{21}$ found that dextrose exerted a reducing action equivalent to about one-thirteenth of the reducing power of levulose. This ratio appeared to be constant regardless of the relative concentrations of levulose and dextrose.

Important contributions to the method have been made by Zerban and Sattler ${ }^{22}$ and by Schuette and Terrill. ${ }^{23}$

Nyns's method proved extremely serviceable for the estimation of levulose in numerous products. For immediate purposes it was used in unmodified form, but the long period of digestion (23/2 hours) made it tedious and time consuming. In order to render the method more convenient and reliable we suggest the modifications described below which permit a shorter time of digestion, an accurate and rapid method of copper determination, occasional agitation during reduction, and higher concentrations of copper sulphate $(25.3 \mathrm{~g})^{24}$ in Ost's reagent. The agitation of the solution during reduction was

18 Bull. assoc. école sup. brasserie Louvain, January, 1898.

20 Sucr. Belge, vol. 44, p. 210, 1924. Bull. assoc. école brasserie Louvain, vol. 25, p. 63, 1925. C. A., vol. 19 , p. 1236,1925

21 J. Assoc. Official Agri. Chem., vol. 9, p. 178, 1926.

22 Ind. Eng. Chem., vol. 2, p. 307, 1930.

23 J. Am. Chem. Soc., vol, 52, p. $4960,1930$.

Although the articles by Zerban and Sattler, and Schuette and Terrill, have a direct bearing on the present article, lack of available space prevents a detailed discussion of their conclusions.

24 Nyns specified $15 \mathrm{~g}$ of copper sulphate. For a discussion of the concentration of copper see article by Zerban and Sattler, footnote 22. 
suggested by Zerban and Sattler in order to obviate the unequal distribution of copper, an occurrence which we also had observed in analyzing samples of high levulose concentration.

\section{EFFECT OF TIME AND TEMPERATURE UPON THE REDUCTION REACTION}

In an effort to shorten the $2 \frac{1}{2}$-hour period of digestion specified by Nyns the reduction was carried out at various temperatures, the amount of copper reduced being determined at appropriate intervals of time. Parallel experiments were conducted in which the samples contained either pure levulose or levulose admixed with known weights of dextrose. The temperatures selected were $48.6^{\circ}, 54.8^{\circ}$, and $58.8^{\circ} \mathrm{C}$. The experimental results are shown diagrammatically in Figure 1. The reduction occurs relatively rapidly in the early stages

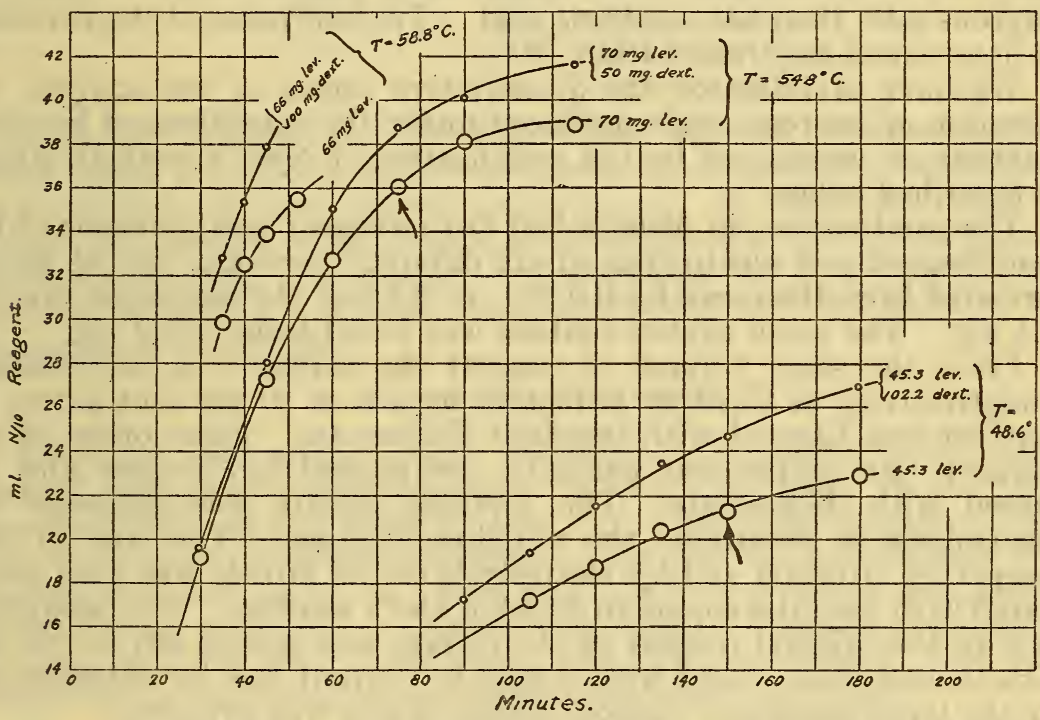

FIgURe 1.-Rate of reduction of copper in Ost's solution by levulose at various temperatures

of the reaction and continues more slowly for an indefinite period. The terminal point of $2 \frac{1}{2}$ hours selected by Nyns is evidently arbitrary and does not represent a definite end point. The filtrate from the reduced copper continues to reduce more copper even upon standing at room temperature.

The curves at $54.8^{\circ}$ and even at $58.8^{\circ}$ show a retardation in the rate of precipitation in the later stages of the reaction and permit the arbitrary selection of a terminal point. For the reduction at $54.8^{\circ}$ the reaction approaches completion in about 75 minutes, or one-half the time specified by Nyns. This period was deemed sufficiently convenient for regular operation, and moreover, the reducing effect of dextrose was found to be about one-thirteenth of that of levulose, as had proved to be the case with Nyns's original method. For further investigation, therefore, the temperature of $55^{\circ} \mathrm{C}$. and the time of 75 minutes were selected. 


\section{AN ELECTROMETRIC METHOD FOR THE DETERMINATION OF REDUCED COPPER}

In Nyns's process for the selective determination of levulose the most tedious or most uncertain step has in the authors' experience been the determination of reduced copper. The most expeditious method is the permanganate titration process originally devised by Mohr and adopted by Nyns for his method. The permanganate method has in practice proved less reliable and convenient than theoretical considerations would lead one to expect and has, in general, had but limited application.

A priori considerations led to the belief that if potassium dichromate could be substituted for permanganate the defects inherent in processes which required the use of the latter reagent could be eliminated. Of greatest importance for the present purposes it permits the use of hydrochloric acid which has a greater solvent effect on cuprous salts than has sulphuric acid. The end point of the titration is determined electrometrically. ${ }^{25}$

We have investigated the quantitative aspect of the analysis by titration of cuprous oxide produced under the conditions of levulose analysis as carried out by the modification of Nyns's method, which is described below.

The total copper in $50.00 \mathrm{ml}$ of Ost's reagent was determined by acidification and electrolysis of six different portions, five of which deviated from the mean by $0.0,0.1$, or $0.2 \mathrm{mg}$, the remaining one by $0.4 \mathrm{mg}$. The mean copper content was found to be $320.2 \mathrm{mg}$.

From the same volume of reagent the copper was precipitated quantitatively as $\mathrm{Cu}_{2} \mathrm{O}$ by reduction by a 5 or 10 per cent excess of levulose and titrated with standard dichromate. From other $50 \mathrm{ml}$ portions the copper was partially precipitated by levulose and titrated with dichromate. The acidified filtrate was subjected to electrolysis to determine the unreduced copper. The sum of the copper by titration and by electrolysis of the filtrate was then compared with the total copper in $50 \mathrm{ml}$ of Ost's solution. The acidification of the original reagent or the filtrate was carried out in $500 \mathrm{ml}$ Erlenmeyer flasks fitted with a trap to prevent loss by entrainment in the large volume of carbon dioxide which was evolved.

Electrolysis was carried out in a volume of about $200 \mathrm{ml}$ containing $3 \mathrm{ml}$ of sulphuric acid and $1.5 \mathrm{ml}$ of nitric acid in excess of the acid required to neutralize the carbonate. Copper was deposited on platinum gauze electrodes by a current of about 0.18 ampere flowing for a period of about 17 hours. The absence of copper from the electrolyzed solutions and from the completely reduced Ost's solutions was assured by the absence of discoloration after addition of hydrogen sulphide. Experimental results are shown in Table 12.

${ }_{25}$ G. S. Forbes and E. P. Bartlett, J. Am. Chem. Soc., vol. 35, p. 1527, 1913. 
TABLE 12.-Determinations of reduced copper in $50 \mathrm{ml}$ of Ost's solution by electrometric dichromate titration

[Total copper taken, $320.2 \mathrm{mg}$. $1 \mathrm{ml}$ of dichromate equals $10 \mathrm{mg}$ of copper]

\begin{tabular}{|c|c|c|c|c|}
\hline $\begin{array}{c}\text { Dichro- } \\
\text { mate } \\
0.1573 \mathrm{~N}\end{array}$ & $\begin{array}{l}\mathrm{Cu} \text { in } \\
\text { filtrate }\end{array}$ & $\begin{array}{c}\text { Cu recov } \\
\text { ered }\end{array}$ & Deviation & Error \\
\hline $\begin{array}{c}m l \\
32.06 \\
32.01 \\
32.05 \\
32.05\end{array}$ & $\begin{array}{l}m g \\
0 \\
0 \\
0 \\
0\end{array}$ & $\begin{array}{c}m g \\
320.6 \\
320.1 \\
320.5 \\
320.5\end{array}$ & \begin{tabular}{l}
$m g$ \\
+0.4 \\
\hdashline .1 \\
+.3 \\
+.3
\end{tabular} & $\begin{array}{c}\text { Per cent } \\
+0.13 \\
-.03 \\
+.09 \\
+.09\end{array}$ \\
\hline $\begin{array}{l}32.04 \\
32.03 \\
32.01 \\
30.18\end{array}$ & $\begin{array}{c}0 \\
0 \\
0 \\
18.1\end{array}$ & $\begin{array}{l}320.4 \\
320.3 \\
320.1 \\
319.9\end{array}$ & $\begin{array}{l}+.2 \\
+.1 \\
-.1 \\
-.3\end{array}$ & $\begin{array}{l}+.06 \\
+.03 \\
-.03 \\
-.09\end{array}$ \\
\hline $\begin{array}{l}30.23 \\
30.32 \\
27.18 \\
23.43\end{array}$ & $\begin{array}{l}17.9 \\
17.1 \\
48.2 \\
85.9\end{array}$ & $\begin{array}{l}320.2 \\
320.3 \\
320.0 \\
320.2\end{array}$ & $\begin{array}{c}0 \\
+.1 \\
-.2 \\
0\end{array}$ & $\begin{array}{c}0 \\
+.03 \\
-.06 \\
0\end{array}$ \\
\hline A verage & & 320.26 & \pm 0.17 & \pm 0.05 \\
\hline
\end{tabular}

Evidently the electrometric dichromate titration of cuprous oxide precipitated from Ost's solution is about as accurate as the electrolytic method and incomparably more rapid. An effort was made to extend the method to the determination of copper precipitated from Soxhlet's solution. The results were, however, less satisfactory than those cited above. Further experimentation will be required to determine its reliability.

\section{STANDARD SOLUTIONS}

Potassium dichromate.-This substance is available from commercial sources in very pure form. A quantity of the "C. P." salt was recrystallized and dried at $150^{\circ} \mathrm{C}$. A standard solution, $N \times$ 0.15730 was prepared by dissolving $7.7135 \mathrm{~g}$ of the purified salt and making to 1 liter at $22^{\circ} \mathrm{C}$. One $\mathrm{ml}$ of such a solution is equivalent to $10.00 \mathrm{mg}$ of copper. During subsequent titrations changes of volume resulting from deviations from this temperature were corrected for by assuming an expansion coefficient of 0.00020 .

Ferrous ammonium sulphate. - A solution, $N \times 0.1573$, was prepared by dissolving $61.8 \mathrm{~g}$ of the commercial C. P. hexahydrate, adding $5 \mathrm{ml}$ of concentrated $\mathrm{H}_{2} \mathrm{SO}_{4}$ and making to 1 liter. This solution lost about 0.3 per cent of its reducing power per day. The practice during the present investigation was to titrate it against the dichromate solution at the beginning and at the end of each series of analyses. During the few hours lapse of time no appreciable change was observable.

Ost's solution.-Dissolve $250 \mathrm{~g}$ of $\mathrm{K}_{2} \mathrm{CO}_{3}$ (anhydrous) in about $700 \mathrm{ml}$ of hot water and add $100 \mathrm{~g}$ of pulverized $\mathrm{KHCO}_{3}$. Agitate until completely dissolved. Cool and add with very vigorous agitation a solution of $25.3 \mathrm{~g}$ of pure $\mathrm{CuSO}_{4} \cdot 5 \mathrm{H}_{2} \mathrm{O}$ in 100 to $150 \mathrm{ml}$ of water. Make to 1 liter and filter.

\section{ANALYTICAL PROCEDURE}

Transfer $50 \mathrm{ml}$ of Ost's reagent to a $150 \mathrm{ml}$ Erlenmeyer flask and add by means of an accurately graduated pipette a volume of the solution to be analyzed which contains not more than $92 \mathrm{mg}$ of 
levulose or its equivalent of a levulose-dextrose mixture, remembering that dextrose has about one-twelfth of the reducing power of levulose. Add enough water to make the total volume $70 \mathrm{ml}$. Immerse in a water bath regulated preferably within $0.1^{\circ} \mathrm{C}$. at $55^{\circ} \mathrm{C}$. Digest for exactly 75 minutes, agitating with a rotary motion at intervals of 10 or 15 minutes.

At the expiration of the prescribed time filter the precipitated copper on a closely packed Gooch crucible and wash flask and filter thoroughly without attempting to transfer the precipitate quantitatively. It is well, however, to transfer all of the loose-lying cuprous oxide, leaving in the flask only the small portion which adheres to the walls. Remove the asbestos mat by means of a glass rod and transfer to a $400 \mathrm{ml}$ beaker. Add 5 or $10 \mathrm{ml}$ of water and disintegrate the asbestos mat. Add a carefully measured volume of standard potassium dichromate $(N \times 0.1573)$ in excess of the volume required to oxidize the cuprous oxide. In many cases the expected amount of precipitated copper will be roughly known and it will be possible to gage the volume of dichromate which will supply a 3 to $4 \mathrm{ml}$ excess. If the amount of precipitated copper is not even roughly known it is preferable to add an amount which will supply an assured excess, since a very large excess introduces no uncertainty, provided its volume is accurately measured. Of this volume about $1 \mathrm{ml}$ is added to the original reaction flask in order that the residual cuprous oxide may be dissolved and subsequently added to the remainder of the solution. Add to the Erlenmeyer flask by means of a graduated cylinder about $50 \mathrm{ml}$ of $1: 1 \mathrm{HCl}$. Pour slowly into the $400 \mathrm{ml}$ beaker with constant stirring and continue to stir until the cuprous oxide is completely dissolved. Wash the Erlenmeyer with a jet from the wash bottle, receiving the rinsings in the beaker. Examine the asbestos critically by looking through the bottom of the beaker, which is held above the eye. If any undissolved cuprous oxide remains it can be clearly discerned as dark-colored particles. Immerse the crucible in the acidified solution to dissolve such cuprous oxide as remained in it. Remove the crucible with a glass rod, washing it free from solution. Dilute the solution as thus prepared to about $250 \mathrm{ml}$ and titrate the excess of dichromate with ferrous sulphate electrometrically.

If a large number of samples require analysis the solutions may for convenience be allowed to await the titration after the addition of dichromate and hydrochloric acid.

\section{DETERMINATION OF COPPER-LEVULOSE EQUIVALENTS}

On each of six days a series of analyses was made to determine the copper reduced by varying amounts of levulose. The samples were introduced into the water bath at intervals of six or seven minutes. At the time each sample was immersed or removed all those previously introduced were momentarily agitated by a rotary motion to insure the uniform distribution of cupric copper. At the expiration of 75 minutes the solutions were filtered, washed, and prepared for titration by one worker, while the other performed the titration and prepared additional samples for analysis. By proceeding in this manner we were enabled to perform conveniently about 25 analyses in a period of about four hours. An analyst working alone can perform about 17 analyses in the same period of time. 
The experimental results are assembled in Table 13 and plotted in Figure 2. The experiments were arranged in such a manner as to show the reproducibility of duplicate experiments performed, on the same day, on different days, and after an extended period of time. Three different preparations of Ost's solution were used for the analyses. One solution was used on March 26, 1931, and preserved for the final series on April 28 in order to be assured that no change in results occurred after an extended period of aging.

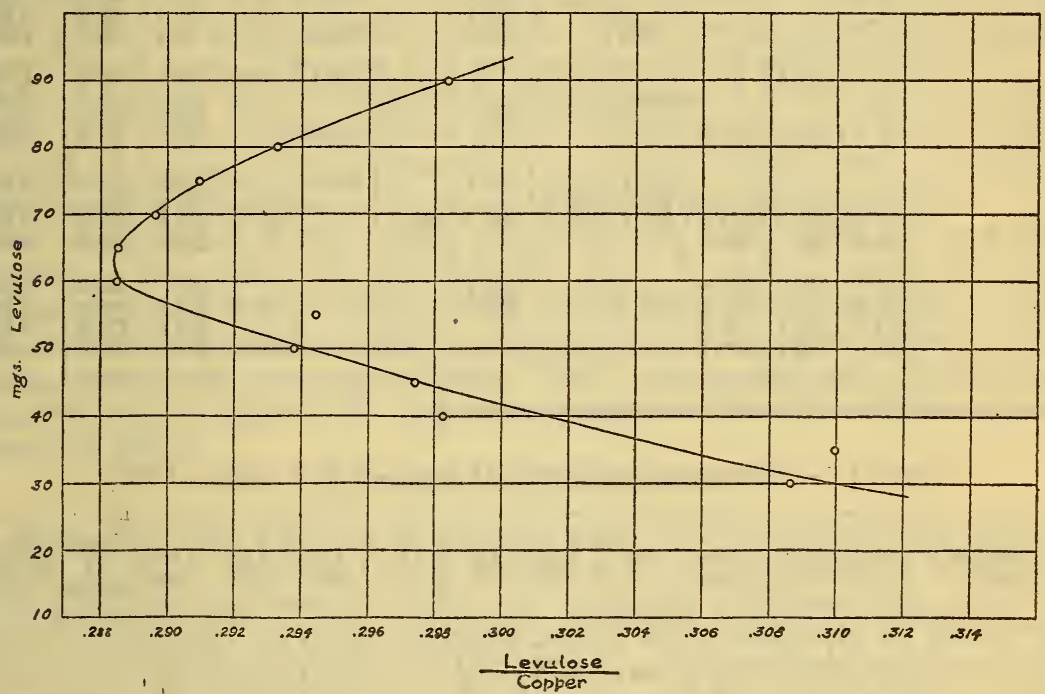

FIGURE 3. -Showing the variation of the levulose-to-copper ratio with varied concentrations of levulose

The averaged values of the copper precipitated by each quantity of levulose are given in column 11. The weights of levulose divided by the respective weights of copper yielded the factors which were serviceable for conversion of copper into its levulose equivalent. These factors are plotted as a function of copper in Figure 3.

Preliminary alculations made to adjust the experimental data by the method of least squares failed to yield an equation which represented the data accurately. The adjustment was accordingly made by drawing Figure 3 on a large scale. In determining the curve the points were weighted according to the number of determinations included in each average. The equivalents for integral weights of copper are tabulated in Table 23, page 440. 
77

280

260

$\begin{array}{ll}\frac{c}{w} & 220 \\ \frac{u}{0} & \\ \frac{0}{0} & \\ ن & 200\end{array}$

47 - -9 H

60

40

174

In

$+1$

20

IT

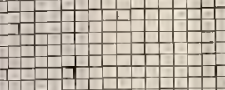

แै

$\frac{\frac{c}{2}}{\frac{\alpha}{0}}$

180

160

140

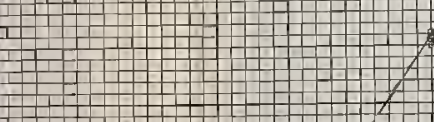

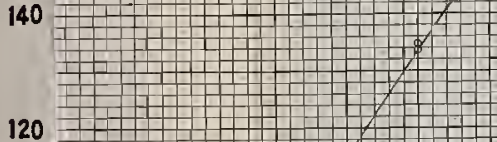

120

구

100

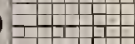
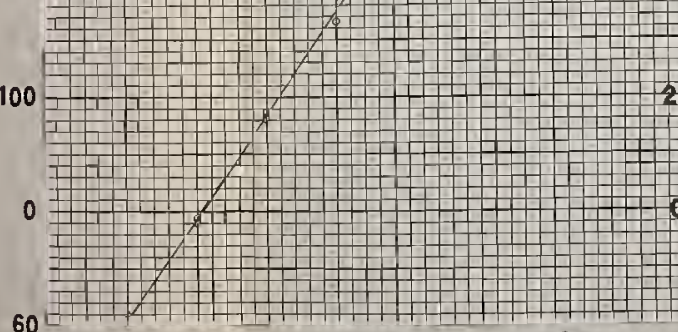

60

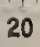

30

40

50

60

70

90

MILLIGRAMS OF LEVULOSE MILLIGRAMS OF LEVULOSE
FIgORE 2.-Copper in Ost's solution reduced by levulose in 75 minutes at $55^{\circ} \mathrm{C}$. according to the modified Nyns method
99075-32. (Fsce p. 427 .) 
TABLE 13.-Copper-levulose equivalents

[Milligrams of copper reduced by varying amounts of levulose]

\begin{tabular}{|c|c|c|c|c|c|c|c|c|c|c|c|c|}
\hline$\underset{\text { (mg) }}{\text { Levulose }}$ & $\underset{26}{\operatorname{Mar}}$ & $\underset{27}{\operatorname{Mar}}$ & $\underset{31}{\operatorname{Mar} .}$ & $\mathrm{Apr}_{3}$. & $\mathrm{Apr}_{3}$ & Apr. & Apr. & $\underset{28}{\text { Apr. }}$ & ${ }_{28}^{A p r}$ i & $\begin{array}{c}\text { A ver- } \\
\text { age }\end{array}$ & justed & $\begin{array}{l}\text { Ratio: } \\
\text { Levu- } \\
\text { lose } \\
\text { Copper }\end{array}$ \\
\hline & & & & 27.3 & 27.0 & 11. 6 & & 26.6 & & 11. 6 & 11.7 & $\begin{array}{l}310 \\
773\end{array}$ \\
\hline & 43.7 & $\ldots$ & 44.0 & & & 42.1 & & $\begin{array}{l}20.0 \\
42.6\end{array}$ & 45.4 & 43. 6 & $\begin{array}{l}20.7 \\
43.7\end{array}$ & $\begin{array}{l}3.738 \\
3.444\end{array}$ \\
\hline & & & & 78.0 & & $\begin{array}{l}77.8 \\
71.1\end{array}$ & & 78.9 & & $\begin{array}{l}78.2 \\
78.2\end{array}$ & $\begin{array}{l}61.0 \\
78.7\end{array}$ & $\begin{array}{l}\text { 3. } 342 \\
\text { 3. } 197\end{array}$ \\
\hline 30 & 97.2 & 96.1 & 97.4 & & & & & 97.2 & 97.4 & 97.1 & 96.7 & 3. 086 \\
\hline & & & & $\begin{array}{l}112.9 \\
134.7\end{array}$ & & 133.5 & & & & \begin{tabular}{|l|}
112.9 \\
134.1
\end{tabular} & $\begin{array}{l}114.7 \\
132.5\end{array}$ & $\begin{array}{l}3.100 \\
2.983\end{array}$ \\
\hline & 152.3 & 151.8 & 149.9 & & & & & 151.0 & 151.5 & 151.3 & 151.0 & 2. 974 \\
\hline & & & & 170.4 & 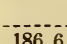 & 169.3 & & 170.8 & & $\begin{array}{ll}170.2 \\
186.8\end{array}$ & $\begin{array}{l}170.0 \\
189\end{array}$ & 2. 938 \\
\hline- & $\begin{array}{l}209.6 \\
223.0\end{array}$ & $\begin{array}{r}208.2 \\
226.4\end{array}$ & $\begin{array}{r}210.6 \\
226.6\end{array}$ & 206.7 & 206.1 & 208.0 & 208.0 & & 206.6 & $\begin{array}{l}208.0 \\
225.3\end{array}$ & $\begin{array}{l}208.0 \\
225.3\end{array}$ & $\begin{array}{l}2.885 \\
2.885\end{array}$ \\
\hline & $\begin{array}{r}242.0 \\
257.7\end{array}$ & $\begin{array}{r}242.6 \\
258.3\end{array}$ & $\begin{array}{r}241.6 \\
257.9\end{array}$ & 257.8 & & $\begin{array}{l}240.4 \\
257.2\end{array}$ & & 257.8 & 258.1 & $\begin{array}{l}241.7 \\
257.8\end{array}$ & $\begin{array}{l}242.0 \\
257.8\end{array}$ & $\begin{array}{l}2.896 \\
2.909\end{array}$ \\
\hline 90 & $\begin{array}{l}272.1 \\
301.5\end{array}$ & $\begin{array}{l}270.1 \\
302.7\end{array}$ & $\begin{array}{r}273.3 \\
300.1\end{array}$ & & & & & & 302.2 & \begin{tabular}{|l}
272.8 \\
301.6
\end{tabular} & $\begin{array}{l}273.0 \\
301.5\end{array}$ & $\begin{array}{r}2.933 \\
2.984\end{array}$ \\
\hline
\end{tabular}

1 Analyses performed with same Ost's solution as on Mar. 26.

TABLE 14.-Deviations of individual analyses from adjusted table

\begin{tabular}{|c|c|c|c|c|c|c|c|c|c|c|c|c|}
\hline $\begin{array}{l}\text { Levulose } \\
\text { (mg) }\end{array}$ & $\underset{26}{\operatorname{Mar}}$ & $\underset{27}{\operatorname{Mar}}$ & $\underset{31}{\operatorname{Mar}}$ & $\mathrm{Apr}_{3}$ & $\mathrm{Apr}_{3}$ & $\mathrm{Apr}_{8}$ & Apr. & ${ }_{28}^{\mathrm{Apr}}$ & ${ }_{28}^{A p r}$. & $\begin{array}{c}\text { Aver- } \\
\text { age }\end{array}$ & $\begin{array}{l}\text { Sum } \\
\text { of } \\
\text { errors }\end{array}$ & $\begin{array}{l}\text { Mean } \\
\text { devia- } \\
\text { tion }\end{array}$ \\
\hline & & & & +0.6 & +0.3 & $\begin{array}{l}-0.1 \\
-.6\end{array}$ & & -0.1 & & -0.1 & & \\
\hline & 0 & & +0.3 & & +0.3 & -1.0 & & -1.1 & +1.7 & -.1 & $\cdots$ & \\
\hline & & & & -7 & & $\begin{array}{l}+.7 \\
-.9\end{array}$ & & +.2 & & $\begin{array}{l}+.7 \\
+.5\end{array}$ & +6.2 & \\
\hline 30. & +0.5 & -0.6 & +.7 & & & & & +.5 & +.7 & -.6 & -5.7 & 0.63 \\
\hline+4 & & & & -1.8 & & & & & & -1.8 & & \\
\hline & 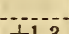 & +8 & -11 & +2.2 & & +1.0 & & & 5 & +1.6 & {$[-\ldots$} & $\cdots$ \\
\hline & +1.3 & 7.8 & -1.1 & +.4 & & -.7 & & +.8 & +.0 & $\begin{array}{r}+.3 \\
+.2\end{array}$ & 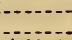 & - \\
\hline & +1.6 & +.2 & +2.6 & $\begin{array}{l}-2.3 \\
-1.3\end{array}$ & $\begin{array}{l}-2.7 \\
-1.9\end{array}$ & 0 & 0 & & -1.4 & -2.5 & $\begin{array}{l}+11.4 \\
-13.2\end{array}$ & 1.2 \\
\hline & -2.3 & $\begin{array}{r}+1.1 \\
+.6\end{array}$ & $\begin{array}{r}+1.3 \\
-\quad 4\end{array}$ & & & -1.6 & & & & $\frac{0}{-3}$ & & \\
\hline & 0 & $\begin{array}{r}+5 \\
\end{array}$ & +.1 & 0 & & -.5 & & 0 & +.4 & $0^{\circ}$ & 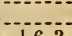 & $\cdots$ \\
\hline $80-.$. & $\overline{0}^{-9}$ & $\begin{array}{r}+.1 \\
+1.2\end{array}$ & $\begin{array}{r}+.3 \\
-1.4\end{array}$ & & & & & $\cdots$ & +.7 & +.2 & $\begin{array}{l}+6.3 \\
-7.1\end{array}$ & .6 \\
\hline
\end{tabular}

1 Analyses performed with same Ost's solution as on Mar. 26.

\section{DISCUSSION OF ERRORS}

In Table 14 are shown the deviations of the individual analyses from the adjusted table of equivalents. For convenience of critical study these experiments have been divided into three groups representing, respectively, nigh, medium, and low concentrations of levulose. The essential agreement of positive with negative residuals in each group shows that the adjusted table represents fairly the experimental data. For the whole series the average deviation of a single experiment is $0.8 \mathrm{mg}$ of copper. In the group of high levulose concentrations (65 to $90 \mathrm{mg}$ ) the mean error of a single determination is $0.6 \mathrm{mg}$ of copper. The average weight of copper reduced in this group of analyses was 
$273 \mathrm{mg}$. The mean error of analysis was therefore but 0.2 per cent of the quantity measured.

In the median range of levulose concentrations (35 to $60 \mathrm{mg}$ ) the average deviation from the adjusted copper equivalents is $1.2 \mathrm{mg}$ of copper. This error is twice as great as that in either of the two other groups. The reason for this is not far to seek, for an inspection of Figure 3 shows that this is the region of greatest curvature of the levulose-copper ratio, and relatively large variations occur with slight alterations of conditions. The average weight of copper reduced in this group of analyses was $176 \mathrm{mg}$. The average error of a single experiment was, therefore, 0.7 per cent of the quantity measured.

In the range of low levulose concentrations ( 5 to $30 \mathrm{mg}$ ) the mean error of a single determination was $0.63 \mathrm{mg}$ of copper. The average weight of copper reduced was $58.8 \mathrm{mg}$. The average error of a single analysis was, therefore, 1.1 per cent of the quantity measured.

In recapitulation the mean errors in the high, median, and low groups of analyses were, respectively, $0.2,0.7$, and 1.1 per cent of the quantities measured. This result corroborates the prediction made by Jackson ${ }^{26}$ that the higher concentrations of copper in Ost's solution, permitting correspondingly high concentrations of levulose, yielded analytical results of greater precision than the Ost's reagent used by Nyns.

\section{EFFECT OF DEXTROSE}

In conjunction with the analyses of pure levulose solutions described above similar analyses were made on levulose-dextrose mixtures. The experimental results which are arranged in descending order of ratio of levulose to total reducing sugar are assembled in Table 15. The total copper precipitated (column 4) was converted into its levulose equivalent by reference to Table 23 , page 440 . The result is designated in column 5 of Table 15, "apparent levulose." The difference between apparent levulose and the true levulose taken represents in terms of milligrams of levulose the reducing effect of the weight of dextrose taken. The quotient of the weight of dextrose divided by the excess of apparent over the true levulose is the number of milligrams of dextrose which is equivalent in reducing power to $1 \mathrm{mg}$ of levulose. These values are given in column 6 of Table 15 and also in Table 16, which permits a more discriminating analysis of the results. It is at once apparent from Table 16 that even for extreme variations of levulose and dextrose concentrations no considerable systematic deviations from a constant dextrose equivalent of levulose occur. The experiments include a range of ratios of levulose to total reducing sugar (column 1 of Table 15) varying from 2.9 to 75 per cent. No attempt was made to determine the reducing action of dextrose for mixtures of higher levulose ratio, since for such mixtures the total effect of dextrose amounts to a very small correction, and any probable deviation from a constant reducing power would be negligible.

${ }_{26}$ J. Assoc. Official Agri. Chem., vol. 13, p. 200, 1930. 
TABLE 15.-Reduction of levulose-dextrose mixtures

[Modified Nyns method]

\begin{tabular}{|c|c|c|c|c|c|c|c|c|}
\hline $\begin{array}{c}\text { Ratio: } \\
\begin{array}{c}\text { Levu- } \\
\text { lose }\end{array} \\
\begin{array}{c}\text { Total } \\
\text { sugar }\end{array}\end{array}$ & $\begin{array}{l}\text { Levu- } \\
\text { lose } \\
\text { taken }\end{array}$ & $\begin{array}{l}\text { Dex- } \\
\text { trose } \\
\text { taken }\end{array}$ & $\begin{array}{l}\text { Copper } \\
\text { precip- } \\
\text { itated }\end{array}$ & $\begin{array}{l}\text { Appar- } \\
\text { entlev- } \\
\text { ulose } \\
\text { found }\end{array}$ & $\begin{array}{l}\mathrm{Mg} \\
\text { Dex- } \\
\text { trose } \\
\overbrace{\mathrm{mg}} \\
\begin{array}{l}1 \\
\text { levu- } \\
\text { lose }\end{array}\end{array}$ & $\begin{array}{c}\text { Dex- } \\
\text { trose } \\
\text { taken } \\
\div 12.4\end{array}$ & $\begin{array}{l}\text { Cor- } \\
\text { rected } \\
\text { levulose } \\
\text { found } 1\end{array}$ & $\begin{array}{l}\text { Error of } \\
\text { lerulose } \\
\text { taken }\end{array}$ \\
\hline $\begin{array}{c}\text { Per cent } \\
100.0 \\
75.0 \\
75.0 \\
61.6\end{array}$ & $\begin{array}{r}m g \\
75 \\
75 \\
50 \\
80\end{array}$ & $\begin{array}{l}m g \\
0 \\
25 \\
16.7 \\
50\end{array}$ & $\begin{array}{l}m g \\
257.8 \\
264.9 \\
174.7 \\
284.3\end{array}$ & $\begin{array}{l}m g \\
75.0 \\
77.4 \\
51.3 \\
83.9\end{array}$ & $\begin{array}{l}10.4 \\
12.8 \\
12.8\end{array}$ & \begin{tabular}{l}
$m g$ \\
\hdashline 2.0 \\
1.35 \\
4.0
\end{tabular} & $\begin{array}{l}m g \\
75.4 \\
49.95 \\
79.9\end{array}$ & $\begin{array}{c}\text { Per cent } \\
+0.5 \\
-.1 \\
-.1\end{array}$ \\
\hline $\begin{array}{l}58.4 \\
54.5 \\
50.0 \\
50.0\end{array}$ & $\begin{array}{l}70 \\
60 \\
75 \\
50\end{array}$ & $\begin{array}{l}50 \\
50 \\
75 \\
50\end{array}$ & $\begin{array}{l}255.6 \\
223.7 \\
276.3 \\
184.6\end{array}$ & $\begin{array}{l}74.3 \\
64.5 \\
81.1 \\
53.8\end{array}$ & $\begin{array}{l}11.6 \\
11.1 \\
12.3 \\
12.8\end{array}$ & $\begin{array}{l}4.1 \\
4.1 \\
6.1 \\
4.0\end{array}$ & $\begin{array}{l}70.2 \\
60.4 \\
75.0 \\
49.8\end{array}$ & $\begin{array}{c}+.3 \\
+.7 \\
0 \\
-.2\end{array}$ \\
\hline $\begin{array}{l}47.4 \\
45.5 \\
44.2 \\
41.2\end{array}$ & $\begin{array}{l}45 \\
25 \\
80 \\
70\end{array}$ & $\begin{array}{r}50 \\
30 \\
100 \\
100\end{array}$ & $\begin{array}{r}164.7 \\
87.6 \\
295.2 \\
268.0\end{array}$ & $\begin{array}{l}48.7 \\
27.5 \\
87.7 \\
78.4\end{array}$ & $\begin{array}{l}13.5 \\
12.0 \\
13.0 \\
11.9\end{array}$ & $\begin{array}{l}4.0 \\
2.4 \\
8.1 \\
8.1\end{array}$ & $\begin{array}{l}44.7 \\
25.1 \\
79.6 \\
70.3\end{array}$ & $\begin{array}{r}-.7 \\
+.4 \\
-.5 \\
+.4\end{array}$ \\
\hline $\begin{array}{l}\text { Mean } \\
\text { error }\end{array}$ & & & & & & & 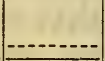 & 0.35 \\
\hline $\begin{array}{l}37.5 \\
37.5 \\
33.3 \\
31.0 \\
25.0\end{array}$ & $\begin{array}{l}60 \\
30 \\
75 \\
45 \\
50\end{array}$ & $\begin{array}{r}100 \\
50 \\
150 \\
100 \\
150\end{array}$ & $\begin{array}{l}240.3 \\
113.0 \\
293.6 \\
179.9 \\
211.3\end{array}$ & $\begin{array}{l}69.5 \\
34.6 \\
87.1 \\
52.6 \\
61.0\end{array}$ & $\begin{array}{l}10.5 \\
10.9 \\
12.3 \\
13.1 \\
13.7\end{array}$ & $\begin{array}{c}8.1 \\
4.05 \\
12.1 \\
8.1 \\
12.1\end{array}$ & $\begin{array}{l}61.4 \\
30.55 \\
75.0 \\
44.5 \\
48.9\end{array}$ & $\begin{array}{c}+2.3 \\
+1.8 \\
0 \\
-1.1 \\
-2.2\end{array}$ \\
\hline $\begin{array}{l}25.0 \\
23.1 \\
23.1 \\
16.7 \\
15.4\end{array}$ & $\begin{array}{l}25 \\
30 \\
15 \\
60 \\
50\end{array}$ & $\begin{array}{r}75 \\
100 \\
50 \\
300 \\
275\end{array}$ & $\begin{array}{r}99.3 \\
126.5 \\
59.6 \\
286.3 \\
244.9\end{array}$ & $\begin{array}{l}30.9 \\
38.3 \\
19.6 \\
84.5 \\
71.0\end{array}$ & $\begin{array}{l}13.3 \\
12.0 \\
10.9 \\
12.2 \\
13.1\end{array}$ & $\begin{array}{c}6.1 \\
8.1 \\
4.1 \\
24.25 \\
22.2\end{array}$ & $\begin{array}{l}24.8 \\
30.2 \\
15.5 \\
60.25 \\
48.8\end{array}$ & $\begin{array}{r}-.6 \\
-.7 \\
+3.3 \\
+.4 \\
-2.4\end{array}$ \\
\hline $\begin{array}{l}\text { Mean } \\
\text { error }\end{array}$ & & & & & & & & 1.5 \\
\hline $\begin{array}{r}13.0 \\
10.4 \\
9.8 \\
8.3 \\
5.7 \\
4.8 \\
2.9\end{array}$ & $\begin{array}{l}15 \\
40 \\
30 \\
45 \\
30 \\
25 \\
15\end{array}$ & $\begin{array}{l}100 \\
350 \\
275 \\
500 \\
500 \\
500 \\
500\end{array}$ & $\begin{array}{r}74.9 \\
225.0 \\
180.8 \\
282.9 \\
238.1 \\
207.7 \\
178.7\end{array}$ & $\begin{array}{l}24.0 \\
64.9 \\
52.8 \\
83.4 \\
68.8 \\
60.0 \\
52.3\end{array}$ & $\begin{array}{l}11.1 \\
14.0 \\
12.1 \\
13.0 \\
12.9 \\
14.3 \\
13.4\end{array}$ & $\begin{array}{r}8.1 \\
28.3 \\
22.2 \\
40.4 \\
40.4 \\
40.4 \\
40.4\end{array}$ & $\begin{array}{l}15.9 \\
36.7 \\
30.6 \\
43.4 \\
28.4 \\
19.6 \\
11.9\end{array}$ & $\begin{array}{r}+6.0 \\
-8.2 \\
+2.0 \\
-3.6 \\
-5.3 \\
-21.6 \\
-20.6\end{array}$ \\
\hline $\begin{array}{c}\text { Mean } \\
\text { error. }\end{array}$ & & & & & & & & 9.8 \\
\hline
\end{tabular}

1 Column 5 minus column 7.

The mean of all the values given in Table 16 is 12.4 . The most generally useful part of the table will be that which is applicable to samples whose compositions lie in the lower left quadrant bounded by levulose, 45 to $80 \mathrm{mg}$, and dextrose, to $150 \mathrm{mg}$. Such samples may range from 20 to 100 per cent in ratio of levulose to total reducing sugar. Within this quadrant the mean value for the reducing action of dextrose is 12.3 in essential agreement with the average of all determinations made. If we take the upper left-hand quadrant bounded by levulose, 15 to $50 \mathrm{mg}$, and dextrose, to $150 \mathrm{mg}$ (overlapping the quadrant previously considered), the mean value is 12.3 . The upper right-hand quadrant bounded by levulose, 15 to $50 \mathrm{mg}$, and dextrose, 250 to $500 \mathrm{mg}$, has the mean value 13.1 . 
TABLE 16.-Reducing action of dextrose by the modified Nyns method

[Tabulated figures indicate the number of milligrams of dextrose which is equivalent in reducing power to $1 \mathrm{mg}$ of levulose]

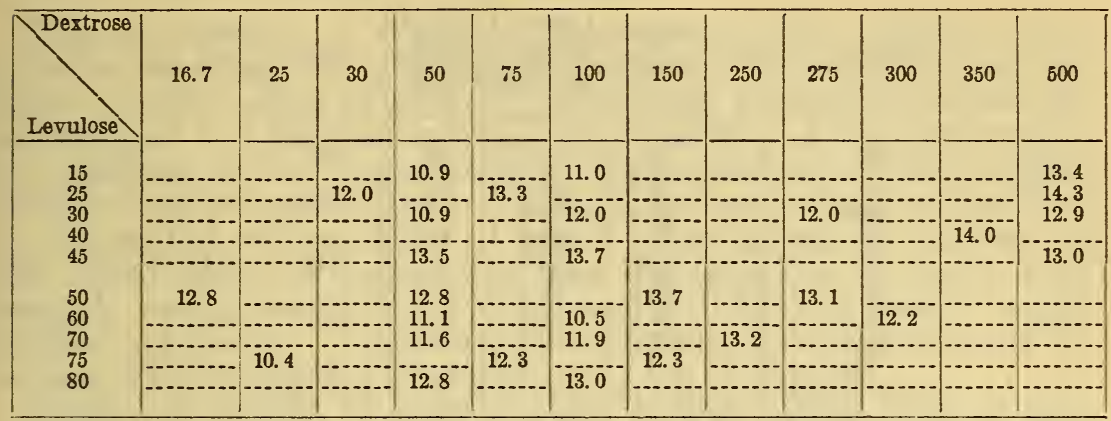

Viewed as a whole the data in Table 16 seem to indicate that for constant amounts of dextrose, its reducing effect is practically independent of the concentration of levulose. For greatly increased concentrations of dextrose (for example, 350 to $500 \mathrm{mg}$ ) its reducing power seems to decrease slightly. The most disturbing feature is the variability of individual analyses. These variations will, however, seriously affect the precision of the levulose analysis only when the dextrose content of the sample is relatively high.

In order to ascertain the degree of precision which may be expected in the analysis of levulose-dextrose mixtures, we have divided Table 15 into three sections, in each of which the mean error of analysis has been computed. The first group of analyses indicates that sugar mixtures ranging from 40 to 100 per cent levulose can be analyzed with a mean error of about 0.35 per cent, which is but slightly greater than the error of analysis of pure levulose solutions. Samples ranging from about 15 to 40 per cent ratio of levulose to total sugar can be analyzed with a mean error of about 1.5 per cent.

Below a 15 per cent ratio the dextrose corrections become very large, and the errors of analysis increase greatly. Even within this range, however, the analytical results have some significance. One could, for example, determine the ratio of levulose to total sugar within one-half of 1 unit. For such low ratios of levulose it is probable that a direct determination of dextrose ${ }^{27}$ would yield more reliable results.

\section{EFFECT OF SUCROSE}

A limited number of analyses were made of levulose-sucrose mixtures in order that the modified method described above might be available for the determination of levulose in the products of the cane-sugar industry. In harmony with the conclusions of Zerban and Sattler we find that the effect of sucrose is small. The analytical results are given in Table 17. The weight of copper precipitated by sucrose in the presence of levulose can be represented by the formula:

$$
\mathrm{mg} \mathrm{Cu}=3.32 S-0.31 S^{2}+0.27
$$

in which $S$ is the number of grams of sucrose. The equation is valid only between 1 and $5 \mathrm{~g}$ of sucrose.

n7 Kline and Acree, B. S. Jour. Research, vol. 5 (R P247), p. 1063, 1930. $99675-32-8$ 
TABLE 17.-Reducing effect of sucrose in the presence of levulose by the modified Nyns method

\begin{tabular}{|c|c|c|c|c|c|c|}
\hline Levulose & Sucrose & $\begin{array}{l}\text { Copper } \\
\text { precip- } \\
\text { itated }\end{array}$ & $\begin{array}{l}\text { Copper }{ }^{1} \\
\text { precip- } \\
\text { itated by } \\
\text { levulose }\end{array}$ & $\begin{array}{c}\text { Copper } \\
\text { precip- } \\
\text { itated by } \\
\text { sucrose }\end{array}$ & A verage & $\begin{array}{c}\text { Calcu- } \\
\text { lated } \\
\text { copper }{ }^{2}\end{array}$ \\
\hline $\begin{array}{l}m g \\
10 \\
25 \\
50 \\
75 \\
50 \\
75 \\
10 \\
25 \\
50 \\
0\end{array}$ & $\begin{array}{l}g \\
1 \\
1 \\
1 \\
1 \\
2 \\
2 \\
5 \\
5 \\
5 \\
5\end{array}$ & \begin{tabular}{r}
\multicolumn{1}{c}{$m g$} \\
30.5 \\
52.1 \\
172.6 \\
261.1 \\
177.2 \\
261.9 \\
35.3 \\
87.8 \\
179.3 \\
2.4
\end{tabular} & $\begin{array}{r}m g \\
26.7 \\
78.7 \\
170.0 \\
257.8 \\
170.0 \\
257.8 \\
26.7 \\
78.7 \\
170.0\end{array}$ & $\begin{array}{l}m g \\
3.8 \\
3.4 \\
2.6 \\
3.3 \\
7.2 \\
4.1 \\
8.6 \\
9.1 \\
9.3\end{array}$ & $\begin{array}{l}5.65 \\
9.0\end{array}$ & $\begin{array}{l}3.3 \\
5.65\end{array}$ \\
\hline
\end{tabular}

CALCULATED COPPER PRECIPITATED BY INTEGRAL WEIGHTS OF SUCROSE?

\begin{tabular}{|c|c|c|c|c|c|}
\hline Sucrose.................- & 1 & 2 & 3 & 4 & 5 \\
\cline { 2 - 6 } Copper..............mg-- & 3.3 & 5.7 & 7.4 & 8.5 & 9.0 \\
\hline
\end{tabular}

1 From Table 23, p. 440

$2 \mathrm{Cu}(\mathrm{mg})=3.32 \mathrm{~S}-0.31 \mathrm{~S}^{2}+0.27$.

\section{ANALYSIS OF SUGAR MIXTURES CONTAINING LEVULOSE}

\section{INTRODUCTORY}

There are six general methods of analysis from which it is theoretically possible to select three in order to determine the three quantities-total solids, levulose, and dextrose. If, in addition, sucrose is present a Clerget analysis must be performed. Aside from the Clerget analysis the methods to be considered are: (1) Total dry substance by density, refractive index, or desiccation; (2) total reducing sugar by Lane and Eynon titration or other method; (3) Nyns's levulose analysis; (4) aldose by the method of Kline and Acree; (5) direct polarization; and (6) levulose by temperature coefficient.

It is well known that desiccation processes for the determination of total solids are difficult if the sample contains levulose. The difficulty is greatly increased when levulose becomes the predominating substance. We have, therefore, in the early sections of the present article given particular attention to the determination by densimetric and refractometric methods. While these methods yield only apparent dry substance it is probable that the values (especially those derived from refractive index) will be more serviceable than those derived from desiccation methods.

From a mixture containing no optically active or reducing substance but levulose and dextrose, a combination of any two of the methods 2 to 6 (except the combination 3 and 6 ) will yield a complete sugar analysis. In the presence of other optically active substances only combinations 2 and 3,2 and 4 , and 3 and 4 will yield correct results. Combinations 2 and 3 , and 2 and 5 will be considered in detail. Other combinations, and in particular the question of purity determination, will be discussed in subsequent articles. 


\section{DETERMINATION OF LEVULOSE AND DEXTROSE IN MIXTURES BY POLARIZATION AND LANE AND EYNON TITRATION. THE MATHEWS FORMULA}

This combination of analytical processes and the method of calculation described below are valid under the assumptions that the only optically active or reducing substances present in the sample are dextrose and levulose and that the rotation of a sugar mixture is the algebraic sum of the rotations of the constituents whose specific rotations are referred to the concentration of total sugar rather than to the partial concentration of each. ${ }^{28}$ The calculations below are also based upon the assumption that the titrations are made with reagents and procedure to which Lane and Eynon's factors apply without correction. If necessary, the burette readings should be corrected in the manner described on p. 439 (Table 22).

While the method of determination applies strictly only to pure mixtures of levulose and dextrose, it may sometimes be applied to crude mixtures to yield a proximate analysis by neglecting the errors due to optically active impurities. If the sample in question has previously been subjected to acid hydrolysis the error introduced in the analysis of plant juices is usually small.

For a constant ratio of levulose to total reducing sugar the polarization $(P)$ will vary with the concentration of total sugar, while the titration $(T)$ will vary inversely as the concentration. Since for the reducing sugar analysis we usually must dilute the sample, the product, $P \times T$, will vary with the dilution $(D)$, but the product, $\frac{P \times T}{D}$, will vary but slightly with dilution. It is therefore possible to tabulate in a brief space the ratios of levulose to total sugar as functions of the quantities $\frac{P \times T}{D}$ and $T$. The tabulation is given in Table 24, page 442 .

For convenience this method of solution will be referred to in subsequent articles as the Mathews formula. ${ }^{29}$

The rotation of any mixture in saccharimeter degrees at $20^{\circ} \mathrm{C}$. is given by

$$
\begin{aligned}
P_{\left(t=20^{\circ}\right)}=- & {[5.31154+0.0064928(x+y)] x+} \\
& {[3.03537+0.0020837(x+y)] y, }
\end{aligned}
$$

where $x$ and $y$ are the concentrations of levulose and dextrose, respectively, in grams per $100 \mathrm{ml}$.

The total reducing sugar, $S$, as determined by Lane and Eynon's method is given by

$$
S=\frac{100 F}{T}
$$

$T$ is the titer in $\mathrm{ml}$ and is corrected to correspond to the factor $F$ (see p. 421). $\quad F$ is given approximately by the relation

$$
F=119.36+0.0471 T+7.3 R
$$

where $R=\frac{x}{x+y}$.

${ }^{28}$ Vosburgh, J. Am. Chem. Soc., vol. 43, p. 219, 1921

29 This ingenious method of calculation was devised by the junior author. (R. F. J.) 
$S$ in equation (21) is related to the total reducing sugar by

$$
D S=x+y
$$

where $D$ is the number of volumes to which one volume of the solution polarized is diluted for the Lane and Eynon titration.

In constructing Table 24 , page 442 , the quantity $\frac{P \times T}{D}$ was computed for selected values of $T, D$, and $R$ from equations (20), (21), and (22). Since $\frac{P \times T}{D}$ is not exactly linear with $R D$ as varies, a small correction, $c=\frac{f \times D}{T}$, must be applied in which $f$ is a factor given in a supplementary table. An example illustrating the operation of the table is given on page 440 .

\section{CALCULATION OF LEVULOSE IN A LEVULOSE-DEXTROSE MIXTURE FROM ANY METHOD OF TOTAL REDUCING SUGAR ANALYSIS AND THE MODIFIED NYNS'S METHOD}

If a sample has been analyzed for total reducing sugar by any selected method and for levulose by the modification of Nyns's method described above, the resulting data are sufficient for a calculation of levulose and dextrose by a general method of successive approximations. Compute from the reducing sugar analysis the total reducing sugar in a given volume or weight expressed as dextrose, unless the approximate composition of the sample is known. In the latter case refer the copper to the sugar mixture of that composition. From the Nyns's analysis compute the apparent levulose in the same volume or weight of sample. Subtract the apparent levulose from the total sugar to obtain the apparent dextrose. Divide the apparent dextrose by 12.4 and subtract the quotient from the apparent levulose to obtain a new approximation to the levulose content. Subtract the approximate levulose from the total sugar to obtain a truer value for the dextrose, again divide by 12.4, continue the approximation in the same manner until successive calculations show a negligible change in the levulose. For a final calculation the copper reduced in the total sugar analysis must be referred to the sugar mixture of the finally determined composition.

If the sample under examination contains sucrose which has been determined by Clerget analysis the copper precipitated in the Nyns's analysis is first corrected for the sucrose by Table 17 before the method of approximations is applied.

If the total sugar is determined by Lane and Eynon titration and levulose by the modified Nyns's method the tedious calculation described above can be avoided by the method described below.

4. CALCULATION OF LEVULOSE IN A LEVULOSE-DEXTROSE MIXTURE FROM LANE AND EYNON TITRATION AND THE MODIFIED NYNS'S METHOD

In order to avoid the tedious procedure described in the previous paragraph a convenient method of solution was devised applicable when reducing sugar is determined by Lane and Eynon's method. 
Lane and Eynon's factors for levulose-dextrose mixtures (Table 22, p. 439) may be expressed by

$$
F=119.36+0.0471 T+7.3 R
$$

in which $F$ is the factor, $T$ the titer, and $R$ the ratio of levulose to total reducing sugar. The total reducing sugar $(S)$ in a sample is

whence

$$
\frac{100 F}{T}=S
$$

$$
100 \frac{119.36+0.0471 T+7.3 R}{T}=S
$$

The true levulose is

and the apparent levulose is

$$
L=S R
$$

$$
\begin{aligned}
l & =L+0.0808 S(1-R) \\
& =0.9192 S R+0.0808 S
\end{aligned}
$$

whence

$$
S=\frac{l}{0.9192 R+0.0808}
$$

Combining equations (23) and (24)

$$
\frac{T \times l}{100}=(119.36+0.0471 T+7.3 R)(0.9192 R+0.0808)
$$

Equation (25) was solved for varying $R$ and $T$ and plotted in a series of curves in each of which $T$ was constant. These curves were found to be very nearly straight lines, and even for widely varying values of $T$ were but slightly displaced from each other. It was, therefore, possible to tabulate a complete series of values of $R$ for relatively few values of $T$. In solving the analytical data it is merely necessary to multiply the burette reading for the Lane and Eynon titration by the milligrams of apparent levulose in $100 \mathrm{ml}$ and refer the product divided by 100 to Table 25, page 444. Under the proper titration, $T$ (or interpolated between two adjacent columns), the ratio of levulose to total sugar is read directly. An example showing the method of operation is given on page 444 .

\section{SUMMARY}

1. The densities of aqueous levulose solutions are expressed by

$$
\begin{aligned}
& D_{4}^{20}=0.99823+0.0038893 p+0.0000140 p^{2} \\
& D_{4}^{25}=0.99708+0.0038557 p+0.0000139 p^{2}
\end{aligned}
$$

which are valid between 0 and 20 per cent

$$
D_{4}^{20}=0.99936+0.0037842 p+0.0000164 p^{2}
$$

valid between 20 and 70 per cent. 
2. The mean expansion coefficient between $20^{\circ}$ and $25^{\circ} \mathrm{C}$. is

$$
\frac{\Delta D}{\Delta t}=-\left(0.000231+0.00000672 p+0.0000000224 p^{2}\right)
$$

valid between 0 and 20 per cent, and

$$
\frac{\Delta D}{\Delta t}=-\left(0.0002145+0.00000795 p+0.0000000136 p^{2}\right)
$$

valid between 20 and 70 per cent.

3. Corrections to convert the readings of Brix hydrometers standard for sucrose solutions to percentage of levulose have been computed and tabulated.

4. The density of crystalline levulose $\left(\frac{20^{\circ}}{4^{\circ}}\right)$ has been found to be 1.598 .

5. Refractive indices of levulose solutions are represented by the formulas:

$$
\begin{aligned}
& n_{D}^{20}=1.33300+0.0014159 p+0.00000491 p^{2} \\
& n_{D}^{25}=1.33252+0.0014059 p+0.00000487 p^{2}
\end{aligned}
$$

which are valid between 0 and 20 per cent levulose, and

$$
\begin{aligned}
& n_{D}^{20}=1.33344+0.0013625 p+0.000006645 p^{2} \\
& n_{D}^{25}=1.33312+0.0013415 p+0.000006762 p^{2}
\end{aligned}
$$

which are valid between 20 and 63 per cent levulose, and

$$
\begin{aligned}
& n_{D}^{20}=1.33377+0.0013570 p+0.000006680 p^{2} \\
& n_{D}^{25}=1.33345+0.0013360 p+0.000006800 p^{2}
\end{aligned}
$$

valid between 63 and 90 per cent levulose.

6. The saccharimetric normal weight of crystalline levulose is 18.407 at $20^{\circ} \mathrm{C}$. and 19.003 at $25^{\circ} \mathrm{C}$.

7. The normal weights of dilute solutions are represented by

$$
\begin{aligned}
& W_{(t=20)}=18.803-0.01801 c-0.000191 c^{2} \\
& W_{(t=25)}=19.446-0.02061 c-0.000141 c^{2}
\end{aligned}
$$

in which $c=$ grams of levulose in $100 \mathrm{ml}$.

8. A table of concentration corrections for constant normal weights has been computed.

9. For the temperature interval $20^{\circ}$ to $70^{\circ} \mathrm{C}$. each gram of levulose in $100 \mathrm{ml}$ decreases $0.0344^{\circ} \mathrm{S}$ in rotation for each degree rise in temperature. This value appears to be independent of concentration of sugar.

10. Determinations of the copper reduced by levulose in Munson and Walker's method have been made. It is shown that the ratios of the reducing powers of dextrose to levulose are not constant, but are a function of concentration of sugar. 
11. A modification of the Nyns selective reduction method for levulose has been suggested which permits a performance of the analysis in about one-half the time previously specified.

12. An accurate and rapid electrometric method of cuprous oxide analysis by dichromate titration is described.

13. The copper reduced by pure levulose by the modified Nyns method has been determined and tabulated.

14. The reducing power of dextrose has been found to be essentially independent of the concentration of dextrose or levulose, 12.4 $\mathrm{mg}$ of dextrose being equivalent in reducing power to $1 \mathrm{mg}$ of levulose under the conditions prescribed for the modified Nyns's method.

15. The reducing effect of sucrose has been found to be

$$
m g C u=3.32 S-0.31 S^{2}+0.27
$$

in which $S$ is the number of grams of sucrose. The formula is valid only between 1 and $5 \mathrm{~g}$ of sucrose.

16. Methods of calculation of the concentration of levulose in samples analyzed by optical and chemical methods are described.

\section{APPENDIX}

TAELE 18.-Densities of levulose solutions and mean density and expansion coefficients between $20^{\circ}$ and $25^{\circ} \mathrm{C}$.

[All weights corrected to vacuum]

\begin{tabular}{|c|c|c|c|c|c|c|c|c|c|}
\hline Levulose & $D_{4}^{20}$ & $D_{4}^{25}$ & $\frac{-\Delta D}{\Delta t}$ & $\frac{\Delta v}{\Delta t}$ & Levulose & $D_{4}^{20}$ & $D_{4}^{25}$ & $\frac{-\Delta D}{\Delta t}$ & $\frac{\Delta v}{\Delta t}$ \\
\hline $\begin{array}{l}\text { Per } \\
0 \ldots- \\
1 \ldots \\
2 .- \\
3 .- \\
4-.-\end{array}$ & $\begin{array}{l}0.99823 \\
\text { 1. } 00214 \\
\text { 1. } 00607 \\
\text { 1. } 01003 \\
1.01402\end{array}$ & $\begin{array}{l}0.99708 \\
1.00095 \\
1.00484 \\
1.00877 \\
1.01272\end{array}$ & $\begin{array}{r}\times 10^{-6} \\
231 \\
238 \\
245 \\
252 \\
259\end{array}$ & $\begin{array}{r}\times 10^{-6} \\
231 \\
237 \\
243 \\
249 \\
255\end{array}$ & $\begin{array}{c}\text { Per } \\
36-. \\
37- \\
38 . \\
39- \\
40 .-\end{array}$ & $\begin{array}{l}1.1568 \\
1.1618 \\
1.1668 \\
1.1718 \\
1.1769\end{array}$ & $\begin{array}{l}1.1544 \\
1.1583 \\
1.1643 \\
1.1693 \\
1.17435\end{array}$ & $\begin{array}{r}\times 10^{-5} \\
48 \\
49 \\
50 \\
50 \\
51\end{array}$ & $\begin{array}{r}\times 10^{-5} \\
42 \\
42 \\
43 \\
43 \\
43\end{array}$ \\
\hline $\begin{array}{l}5 . \\
6- \\
7- \\
8 .\end{array}$ & $\begin{array}{l}\text { 1. } 01803 \\
\text { 1. } 02207 \\
\text { 1. } 02614 \\
\text { 1. } 03024\end{array}$ & $\begin{array}{l}\text { 1. } 01670 \\
\text { 1. } 02071 \\
\text { 1. } 02475 \\
\text { 1. } 02881\end{array}$ & $\begin{array}{l}266 \\
273 \\
280 \\
287\end{array}$ & $\begin{array}{l}261 \\
267 \\
273 \\
278\end{array}$ & $\begin{array}{l}41 .- \\
42 .- \\
43 .- \\
44 .- \\
45-\end{array}$ & $\begin{array}{l}1.1820 \\
1.1872 \\
1.1923 \\
1.1975 \\
1.2028\end{array}$ & $\begin{array}{l}\text { 1. } 1794 \\
\text { 1. } 1845 \\
1.1897 \\
1.19485 \\
1.20005\end{array}$ & $\begin{array}{l}52 \\
53 \\
53 \\
54 \\
55\end{array}$ & $\begin{array}{l}44 \\
44 \\
45 \\
45 \\
45\end{array}$ \\
\hline $\begin{array}{l}9 . \\
10 . \\
11 . \\
12 .\end{array}$ & $\begin{array}{l}\text { 1. } 03437 \\
\text { 1. } 03853 \\
\text { 1. } 04271 \\
1.04692\end{array}$ & $\begin{array}{l}1.03290 \\
1.03702 \\
1.04118 \\
1.04535\end{array}$ & $\begin{array}{l}294 \\
301 \\
308 \\
315\end{array}$ & $\begin{array}{l}284 \\
290 \\
295 \\
300\end{array}$ & $\begin{array}{l}46- \\
47- \\
48- \\
49 .\end{array}$ & $\begin{array}{l}\text { 1. } 20805 \\
\text { 1. } 2134 \\
1.2187 \\
1.2241\end{array}$ & $\begin{array}{l}1.2053 \\
1.2106 \\
1.2159 \\
1.2212\end{array}$ & $\begin{array}{l}55 \\
56 \\
57 \\
57\end{array}$ & $\begin{array}{l}46 \\
46 \\
46 \\
47\end{array}$ \\
\hline $\begin{array}{l}13 . \\
14\end{array}$ & $\begin{array}{l}\text { 1. } 05116 \\
\text { 1. } 05543\end{array}$ & $\begin{array}{l}1.04955 \\
1.05378\end{array}$ & $\begin{array}{l}323 \\
330\end{array}$ & $\begin{array}{l}307 \\
313\end{array}$ & 50 & 1. 2295 & 1.2266 & 58 & 47 \\
\hline $\begin{array}{l}15 . \\
16 .\end{array}$ & $\begin{array}{l}\text { 1. } 05972 \\
\text { 1. } 06405\end{array}$ & $\begin{array}{l}\text { 1. } 05804 \\
\text { 1. } 05233\end{array}$ & $\begin{array}{l}337 \\
345\end{array}$ & $\begin{array}{l}318 \\
324\end{array}$ & $\begin{array}{l}51- \\
52-\end{array}$ & $\begin{array}{l}\text { 1. } 2349 \\
\text { 1. } 2404 \\
\text { 1. } 2459\end{array}$ & $\begin{array}{l}\text { 1. } 2320 \\
1.2374 \\
1.2429\end{array}$ & $\begin{array}{l}59 \\
59 \\
60\end{array}$ & $\begin{array}{l}47 \\
48 \\
48\end{array}$ \\
\hline $\begin{array}{l}17 . \\
18 . \\
19 .\end{array}$ & $\begin{array}{l}1.06840 \\
1.07278 \\
1.07719\end{array}$ & $\begin{array}{l}\text { 1. } 05664 \\
\text { 1. } 07098 \\
1.07535\end{array}$ & $\begin{array}{l}352 \\
360 \\
367\end{array}$ & $\begin{array}{l}329 \\
336 \\
341\end{array}$ & 54 & $\begin{array}{l}1.2514 \\
1.2570\end{array}$ & $\begin{array}{l}1.2484 \\
1.2539\end{array}$ & $\begin{array}{l}60 \\
61\end{array}$ & $\begin{array}{l}48 \\
48 \\
49\end{array}$ \\
\hline 20. & 1. 08162 & 1. 07975 & $\begin{array}{r}375 \\
\times 10^{-5}\end{array}$ & $\begin{array}{r}347 \\
\times 10^{-5}\end{array}$ & $\begin{array}{l}56 \\
57\end{array}$ & $\begin{array}{l}1.2626 \\
1.2682\end{array}$ & $\begin{array}{l}1.2595 \\
1.2651\end{array}$ & $\begin{array}{l}62 \\
62\end{array}$ & $\begin{array}{l}49 \\
49\end{array}$ \\
\hline & $\begin{array}{l}\text { 1. } 08606 \\
\text { 1. } 09055 \\
\text { 1. } 09507\end{array}$ & $\begin{array}{l}1.0842 \\
1.0886 \\
1.0931\end{array}$ & $\begin{array}{l}38 \\
38 \\
39\end{array}$ & $\begin{array}{l}35 \\
35 \\
36\end{array}$ & 58 & $\begin{array}{l}1.2739 \\
1.2796\end{array}$ & $\begin{array}{l}1.2707 \\
1.2764\end{array}$ & $\begin{array}{l}63 \\
64\end{array}$ & $\begin{array}{l}50 \\
50\end{array}$ \\
\hline $24 \ldots$ & $\begin{array}{l}1.09962 \\
1.10420\end{array}$ & $\begin{array}{l}1.0976 \\
1.0976 \\
1.1022\end{array}$ & $\begin{array}{l}40 \\
41\end{array}$ & $\begin{array}{l}50 \\
36 \\
37\end{array}$ & $\begin{array}{l}60 . \\
61 .\end{array}$ & $\begin{array}{l}1.2853 \\
1.2911\end{array}$ & $\begin{array}{l}\text { 1. } 2821 \\
\text { 1. } 2878\end{array}$ & $\begin{array}{l}64 \\
65\end{array}$ & $\begin{array}{l}50 \\
50\end{array}$ \\
\hline $\begin{array}{l}26 . \\
27 .\end{array}$ & $\begin{array}{l}\text { 1. } 1088 \\
1.11345\end{array}$ & $\begin{array}{l}1.10675 \\
1.11135\end{array}$ & $\begin{array}{l}41 \\
42\end{array}$ & $\begin{array}{l}37 \\
38\end{array}$ & & $\begin{array}{l}1.2969 \\
1.3027\end{array}$ & $\begin{array}{l}1.2936 \\
1.2994\end{array}$ & $\begin{array}{l}66 \\
66\end{array}$ & $\begin{array}{l}51 \\
51\end{array}$ \\
\hline 28. & 1. 1181 & 1. 1160 & 43 & 38 & 64 & 1. 3086 & 1.3052 & 67 & 51 \\
\hline $\begin{array}{l}29-- \\
30-\end{array}$ & $\begin{array}{l}\text { 1. } 1229 \\
1.1276\end{array}$ & $\begin{array}{l}1.1207 \\
1.1254\end{array}$ & $\begin{array}{l}43 \\
44\end{array}$ & $\begin{array}{l}39 \\
39\end{array}$ & & $\begin{array}{l}1.3145 \\
1.3204\end{array}$ & $\begin{array}{l}1.3111 \\
1.3170\end{array}$ & $\begin{array}{l}67 \\
68\end{array}$ & $\begin{array}{l}51 \\
51\end{array}$ \\
\hline $\begin{array}{l}31 \ldots \\
32 \ldots \\
33-. \\
34- \\
35 \ldots\end{array}$ & $\begin{array}{l}1.1324 \\
1.1372 \\
1.14205 \\
1.1469 \\
1.15185\end{array}$ & $\begin{array}{l}1.13015 \\
1.1349 \\
1.1397 \\
1.1446 \\
1.1495\end{array}$ & $\begin{array}{l}45 \\
46 \\
46 \\
47 \\
48\end{array}$ & $\begin{array}{l}40 \\
40 \\
40 \\
41 \\
41\end{array}$ & $\begin{array}{l}68 . \\
69 . \\
70 \ldots \\
71 .\end{array}$ & $\begin{array}{l}1.3323 \\
1.3384 \\
1.3444 \\
1.3505\end{array}$ & $\begin{array}{l}1.3289 \\
1.3349 \\
1.3409 \\
1.3470\end{array}$ & $\begin{array}{l}69 \\
70 \\
70 \\
71\end{array}$ & $\begin{array}{l}52 \\
52 \\
52 \\
53\end{array}$ \\
\hline
\end{tabular}


TABLE 19.-Corrections to readings of Brix hydrometers immersed in levulose solutions

[The corrections at $20^{\circ} \mathrm{C}$. were determined by referring the densities of levulose solutions of known concentration to the sucrose density tables of Plato. The corrections at other temperatures are the algebraic sum of the corrections at $20^{\circ} \mathrm{C}$. and the temperature corrections for sucrose multiplied by the ratios of the expansion coefficients of levulose and sucrose. The hydrometer is assumed to be constructed of Jena

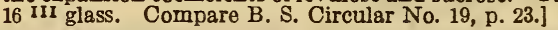

[Standardized for sucrose solutions at $20^{\circ} \mathrm{C}$.]

\begin{tabular}{|c|c|c|c|c|c|c|c|c|c|c|c|c|c|c|c|}
\hline \multirow{3}{*}{$\begin{array}{l}\text { Tem- } \\
\text { perature } \\
{ }^{\circ} \mathrm{C} .\end{array}$} & \multicolumn{15}{|c|}{ Observed Brix } \\
\hline & 0 & 5 & 10 & 15 & 20 & 25 & 30 & 35 & 40 & 45 & 50 & 55 & 60 & 65 & 70 \\
\hline & \multicolumn{15}{|c|}{ Corrections } \\
\hline $\begin{array}{l}18 \ldots \\
19 \\
20 \\
21 \\
22 \\
23\end{array}$ & $\begin{array}{r}-0.09 \\
-.05 \\
.00 \\
+.04 \\
+.10 \\
+.16\end{array}$ & $\begin{array}{r}-0.16 \\
-.10 \\
-.05 \\
.00 \\
+.06 \\
+.12\end{array}$ & $\begin{array}{r}-0.20 \\
-.15 \\
-.09 \\
-.02 \\
+.03 \\
+.10\end{array}$ & $\begin{array}{r}-0.26 \\
-.20 \\
-.13 \\
-.06 \\
+.01 \\
+.07\end{array}$ & $\begin{array}{r}-0.29 \\
-.22 \\
-.15 \\
-.08 \\
-.01 \\
+.08\end{array}$ & $\begin{array}{r}-0.30 \\
-.21 \\
-.14 \\
-.05 \\
+.02 \\
+.10\end{array}$ & $\begin{array}{r}-0.29 \\
-.22 \\
-.13 \\
-.04 \\
+.04 \\
+.13\end{array}$ & $\begin{array}{r}-0.29 \\
-.20 \\
-.12 \\
-.04 \\
+.05 \\
+.13\end{array}$ & $\begin{array}{r}-0.26 \\
-.17 \\
-.09 \\
-.01 \\
+.06 \\
+.17\end{array}$ & $\begin{array}{r}-0.22 \\
-.13 \\
-.05 \\
+.05 \\
+.13 \\
+.23\end{array}$ & $\begin{array}{r}-0.21 \\
-.08 \\
+.02 \\
+.08 \\
+.22 \\
+.32\end{array}$ & $\begin{array}{r}-0.09 \\
.00 \\
+.10 \\
+.20 \\
+.30 \\
+.40\end{array}$ & $\begin{array}{r}+0.01 \\
+.10 \\
+.20 \\
+.30 \\
+.40 \\
+.51\end{array}$ & $\begin{array}{l}+0.1 \\
+.2 \\
+.3 \\
+.4 \\
+.5 \\
+.6\end{array}$ & $\begin{array}{r}+0.23 \\
+.32 \\
+.44 \\
+.56 \\
+.65 \\
+.76\end{array}$ \\
\hline $\begin{array}{l}24- \\
25- \\
26- \\
27- \\
28 .\end{array}$ & $\begin{array}{r}+.21 \\
+.27 \\
+.33 \\
+.40 \\
+.46\end{array}$ & $\begin{array}{r}+.19 \\
+.25 \\
+.32 \\
+.39 \\
+.45\end{array}$ & $\begin{array}{r}+.17 \\
+.25 \\
+.31 \\
+.38 \\
+.46\end{array}$ & $\begin{array}{l}+.15 \\
+.23 \\
+.30 \\
+.38 \\
+.46\end{array}$ & $\begin{array}{r}+.16 \\
+.23 \\
+.33 \\
+.40 \\
+.50\end{array}$ & $\begin{array}{r}+.19 \\
+.27 \\
+.35 \\
+.45 \\
+.54\end{array}$ & $\begin{array}{r}+.21 \\
+.30 \\
+.38 \\
+.48 \\
+.57\end{array}$ & $\begin{array}{l}+.23 \\
+.32 \\
+.41 \\
+.51 \\
+.61\end{array}$ & $\begin{array}{r}+.27 \\
+.36 \\
+.46 \\
+.55 \\
+.64\end{array}$ & $\begin{array}{r}+.33 \\
+.41 \\
+.52 \\
+.60 \\
+.70\end{array}$ & $\begin{array}{r}+.42 \\
+.50 \\
+.60 \\
+.70 \\
+.80\end{array}$ & $\begin{array}{r}+.50 \\
+.59 \\
+.70 \\
+.80 \\
+.90\end{array}$ & $\begin{array}{r}+.61 \\
+.70 \\
+.81 \\
+.92 \\
+1.02\end{array}$ & $\begin{array}{r}+.7 \\
+.8 \\
+.9 \\
+1.0 \\
+1.1\end{array}$ & $\begin{array}{r}+.87 \\
+.96 \\
+1.08 \\
+1.18 \\
+1.29\end{array}$ \\
\hline
\end{tabular}

\section{TABLE 20.-Refractive indices of levulose solutions}

[All data computed from weights in air with brass weights. Immersion readings are referable solely to the scale of arbitrary units proposed by Pulfrich (Zeit. angew. Chemie, p. 1186; 1899). According to this scale, $14.5=1.33300 ; 50.0=1.34650 ;$ and $100.0=1.36464]$

\begin{tabular}{|c|c|c|c|c|c|c|c|c|c|c|c|c|c|}
\hline $\begin{array}{c}\text { Per } \\
\text { cent }\end{array}$ & $n_{D}^{20^{\circ}}$ & $\mid \begin{array}{c}\text { Zeiss } \\
\text { immer- } \\
\text { sion } \\
\text { read- } \\
\text { ing } \\
20^{\circ}\end{array}$ & $n_{D}^{25^{\circ}}$ & \begin{tabular}{|c|} 
Zeiss \\
immer- \\
sion \\
read- \\
ing \\
$25^{\circ}$
\end{tabular} & $\frac{-\Delta n}{\Delta t^{\circ}}$ & $\begin{array}{l}\text { Per } \\
\text { cent }\end{array}$ & $n_{D}^{20^{\circ}}$ & $n_{D}^{25^{\circ}}$ & $\frac{-\Delta n}{\Delta t^{\circ}}$ & $\begin{array}{l}\text { Per } \\
\text { cent }\end{array}$ & $n_{D}^{20^{\circ}}$ & $n_{D}^{25^{\circ}}$ & $\frac{-\Delta n}{\Delta t^{\circ}}$ \\
\hline $\begin{array}{l}0 \\
1 \\
2 \\
3 \\
4\end{array}$ & $\begin{array}{r}1.33300 \\
3442 \\
3585 \\
3729 \\
3874\end{array}$ & \begin{tabular}{l|}
14.50 \\
18.18 \\
21.87 \\
25.63 \\
29.42
\end{tabular} & $\begin{array}{r}1.33252 \\
3393 \\
3535 \\
3678 \\
3822\end{array}$ & $\begin{array}{l}13.25 \\
16.90 \\
20.58 \\
24.29 \\
28.05\end{array}$ & $\begin{array}{r}\times 10^{-6} \\
96 \\
98 \\
100 \\
102 \\
104\end{array}$ & $\begin{array}{l}32 \\
33 \\
34 \\
35 \\
36\end{array}$ & $\begin{array}{r}1.38385 \\
8564 \\
8745 \\
8927 \\
9111\end{array}$ & 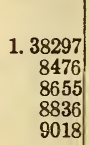 & $\begin{array}{r}\times 10^{-0} \\
175 \\
177 \\
180 \\
183 \\
185\end{array}$ & $\begin{array}{l}64 \\
65 \\
66 \\
67 \\
68\end{array}$ & $\begin{array}{r}\text { 1. } 4479 \\
501 \\
524 \\
547 \\
569\end{array}$ & $\begin{array}{r}1.4467 \\
489 \\
512 \\
535 \\
557\end{array}$ & $\begin{array}{r}\times 10^{-5} \\
24 \\
24 \\
24\end{array}$ \\
\hline $\begin{array}{l}5 \\
6 \\
7 \\
8 \mid \\
9\end{array}$ & $\begin{array}{l}4020 \\
4167 \\
4315 \\
4454 \\
4614\end{array}$ & \begin{tabular}{r|}
33.26 \\
-37.14 \\
41.05 \\
45.03 \\
49.05
\end{tabular} & $\begin{array}{l}3967 \\
4113 \\
4260 \\
4408 \\
4557\end{array}$ & $\begin{array}{l}31.87 \\
35.71 \\
39.61 \\
43.53 \\
47.53\end{array}$ & $\begin{array}{l}106 \\
108 \\
110 \\
112 \\
115\end{array}$ & $\begin{array}{l}37 \\
38 \\
39 \\
40 \\
41\end{array}$ & $\begin{array}{r}9295 \\
9481 \\
9669 \\
9858 \\
1.40048\end{array}$ & \begin{tabular}{l|}
9201 \\
9386 \\
9573 \\
9760 \\
9949
\end{tabular} & $\begin{array}{l}188 \\
190 \\
192 \\
195 \\
197\end{array}$ & $\begin{array}{l}69 \\
70 \\
71 \\
72 \\
73\end{array}$ & $\begin{array}{l}592 \\
615 \\
638 \\
661 \\
684\end{array}$ & $\begin{array}{l}580 \\
602 \\
625 \\
648 \\
672\end{array}$ & $\begin{array}{l}24 \\
24\end{array}$ \\
\hline \begin{tabular}{l|}
10 \\
11 \\
12 \\
13 \\
14
\end{tabular} & $\begin{array}{l}4765 \\
4917 \\
5070 \\
5224 \\
5379\end{array}$ & $\begin{array}{l}53.11 \\
57.19 \\
61.32 \\
65.51 \\
69.75\end{array}$ & $\begin{array}{l}4707 \\
4857 \\
5009 \\
5162 \\
5316\end{array}$ & $\begin{array}{l}\mathbf{5 1 . 5 4} \\
\mathbf{5 5 . 5 7} \\
59.68 \\
63.81 \\
68.00\end{array}$ & $\begin{array}{l}117 \\
119 \\
121 \\
123 \\
125\end{array}$ & $\begin{array}{l}42 \\
43 \\
44 \\
45 \\
46\end{array}$ & $\begin{array}{l}0239 \\
0432 \\
0625 \\
0821 \\
1018\end{array}$ & $\begin{array}{r}\text { 1. } 40140 \\
0331 \\
0524 \\
0718 \\
0914\end{array}$ & $\begin{array}{l}199 \\
202 \\
204 \\
206 \\
208\end{array}$ & $\begin{array}{l}74 \\
75 \\
76 \\
77 \\
78\end{array}$ & $\begin{array}{l}708 \\
731 \\
755 \\
779 \\
803\end{array}$ & $\begin{array}{l}695 \\
719 \\
742 \\
766 \\
790\end{array}$ & $\begin{array}{l}25 \\
25\end{array}$ \\
\hline $\begin{array}{l}15 \\
16 \\
17 \\
18 \\
19\end{array}$ & $\begin{array}{l}5534 \\
5691 \\
5849 \\
6008 \\
6169\end{array}$ & \begin{tabular}{l|}
74.03 \\
78.36 \\
82.75 \\
87.17 \\
91.64
\end{tabular} & $\begin{array}{l}\mathbf{5 4 7 0} \\
\mathbf{5 6 2 6} \\
\mathbf{5 7 8 3} \\
\mathbf{5 9 4 2} \\
6102\end{array}$ & $\begin{array}{l}72.25 \\
76.56 \\
80.92 \\
85.28 \\
89.71\end{array}$ & $\begin{array}{l}127 \\
129 \\
132 \\
135 \\
137\end{array}$ & $\begin{array}{l}47 \\
48 \\
49 \\
50 \\
51\end{array}$ & \begin{tabular}{l|}
1216 \\
1415 \\
1616 \\
1818 \\
2021
\end{tabular} & $\begin{array}{l}1309 \\
1509 \\
1710 \\
1912\end{array}$ & $\begin{array}{l}210 \\
213 \\
214 \\
216 \\
218\end{array}$ & $\begin{array}{l}82 \\
83\end{array}$ & $\begin{array}{l}827 \\
851 \\
875 \\
900 \\
924\end{array}$ & $\begin{array}{l}887 \\
912\end{array}$ & 25 \\
\hline $\begin{array}{l}20 \\
21 \\
22 \\
23\end{array}$ & $\begin{array}{l}6332 \\
6496 \\
6659 \\
6827\end{array}$ & $\begin{array}{r}96.14 \\
100.72 \\
105.37 \\
-\cdots .-\end{array}$ & $\begin{array}{l}6262 \\
6425 \\
6588 \\
6753\end{array}$ & $\begin{array}{r}94.17 \\
98.71 \\
103.31 \\
-. . .-\end{array}$ & \begin{tabular}{l|}
139 \\
142 \\
146 \\
148
\end{tabular} & $\begin{array}{l}52 \\
53 \\
54 \\
55\end{array}$ & \begin{tabular}{l|}
2226 \\
2432 \\
2640 \\
2848
\end{tabular} & $\begin{array}{l}2117 \\
2322 \\
2528 \\
2736\end{array}$ & $\begin{array}{l}219 \\
221 \\
223 \\
224\end{array}$ & $\begin{array}{l}84 \\
85 \\
86 \\
87\end{array}$ & $\begin{array}{r}949 \\
974 \\
999 \\
1.5024\end{array}$ & $\begin{array}{r}936 \\
961 \\
986 \\
1.5011\end{array}$ & $\begin{array}{l}25 \\
25 \\
25 \\
25\end{array}$ \\
\hline $\begin{array}{l}24 \\
25 \\
26 \\
27\end{array}$ & $\begin{array}{l}6996 \\
7166 \\
7336 \\
7506\end{array}$ & & $\begin{array}{l}6921 \\
7088 \\
7258 \\
7426\end{array}$ & & $\begin{array}{l}151 \\
154 \\
157 \\
161\end{array}$ & $\begin{array}{l}56 \\
57 \\
58 \\
59\end{array}$ & $\begin{array}{l}3058 \\
3270 \\
3482 \\
3696\end{array}$ & $\begin{array}{l}2945 \\
3158 \\
3368 \\
3581\end{array}$ & $\begin{array}{l}226 \\
228 \\
229 \\
231\end{array}$ & $\begin{array}{l}88 \\
89 \\
90 \\
91\end{array}$ & $\begin{array}{l}049 \\
074 \\
100 \\
128\end{array}$ & $\begin{array}{l}036 \\
062 \\
087 \\
113\end{array}$ & $\begin{array}{l}25 \\
25 \\
25 \\
25\end{array}$ \\
\hline $\begin{array}{l}28 \\
29 \\
30 \\
31\end{array}$ & $\begin{array}{l}7680 \\
7854 \\
8030 \\
8207\end{array}$ & & $\begin{array}{l}7598 \\
7771 \\
7945 \\
8121\end{array}$ & & $\begin{array}{l}164 \\
166 \\
169 \\
172\end{array}$ & $\begin{array}{l}60 \\
61 \\
62 \\
63\end{array}$ & $\begin{array}{l}3913 \\
4130 \\
4348 \\
4568\end{array}$ & $\begin{array}{l}3797 \\
4014 \\
4232 \\
4451\end{array}$ & $\begin{array}{l}232 \\
233 \\
235 \\
236\end{array}$ & $\begin{array}{l}92 \\
93 \\
94 \\
95\end{array}$ & $\begin{array}{l}151 \\
177 \\
203 \\
230\end{array}$ & $\begin{array}{l}139 \\
165 \\
191 \\
217\end{array}$ & $\begin{array}{l}25 \\
25 \\
25 \\
25\end{array}$ \\
\hline
\end{tabular}


TABLE 21.-Corrections to be applied to saccharimetric readings of levulose solutions when a constant normal weight is used

[Normal weight at $20^{\circ} \mathrm{C} .=18.407 \mathrm{gm}$; normal weight at $25^{\circ} \mathrm{C} .=19.003 \mathrm{gm}$ ]

\begin{tabular}{|c|c|c|c|c|c|c|c|c|}
\hline \multirow{2}{*}{$\begin{array}{l}\text { Polari- } \\
\text { zation }\end{array}$} & \multicolumn{2}{|c|}{ Correction } & \multirow{2}{*}{$\begin{array}{l}\text { Polari- } \\
\text { zation }\end{array}$} & \multicolumn{2}{|c|}{ Correction } & \multirow{2}{*}{$\begin{array}{l}\text { Polari- } \\
\text { zation }\end{array}$} & \multicolumn{2}{|c|}{ Correction } \\
\hline & $20^{\circ} \mathrm{C}$. & $25^{\circ} \mathrm{C}$. & & $20^{\circ} \mathrm{C}$. & $25^{\circ} \mathrm{C}$. & & $20^{\circ} \mathrm{C}$. & $25^{\circ} \mathrm{C}$. \\
\hline $\begin{array}{r}0 \\
5 \\
10 \\
15 \\
20 \\
25 \\
30 \\
35\end{array}$ & $\begin{array}{r}0.00 \\
+.10 \\
.19 \\
.28 \\
.35 \\
.42 \\
.47 \\
.51\end{array}$ & $\begin{array}{r}0.00 \\
+.11 \\
.21 \\
.30 \\
.39 \\
.45 \\
.50 \\
.55\end{array}$ & $\begin{array}{l}40 \\
45 \\
50 \\
52 \\
55 \\
60 \\
65 \\
70\end{array}$ & $\begin{array}{r}+0.54 \\
.56 \\
.57 \\
.58 \\
.57 \\
.56 \\
.53 \\
.50\end{array}$ & $\begin{array}{r}+0.57 \\
.60 \\
.61 \\
.61 \\
.61 \\
.59 \\
.56 \\
.52\end{array}$ & $\begin{array}{r}75 \\
80 \\
85 \\
90 \\
95 \\
100 \\
105 \\
110\end{array}$ & $\begin{array}{r}+0.44 \\
.38 \\
.30 \\
.21 \\
.11 \\
.00 \\
-.11 \\
-.20\end{array}$ & $\begin{array}{r}+0.47 \\
.40 \\
.33 \\
.23 \\
.12 \\
.00 \\
-.14 \\
-.26\end{array}$ \\
\hline
\end{tabular}

Note.-In order to avoid constant repetition of the negative sign, the polarizations of levulose are considered positive. The positive signs in the above table indicate that the negative polarizations of levulose are to be increased to higher negative values.

\section{TABLE 22.-Table of factors for Lane and Eynon's volumetric reducing sugar method}

The factor represents the number of $\mathrm{mg}$ sugar required to reduce $25 \mathrm{ml}$ of Soxhlet reagent. $100 \times \frac{\text { factor }}{\text { titer }}=\mathrm{mg}$ sugar in $100 \mathrm{ml}$.

[In the last three columns are titer corrections corresponding to experimentally determined factors which differ from the tabulated factors by 1,2 , and 3 units. When the experimental factor is greater than the tabulated, the correction is to be subtracted from the observed titer, and vice versa. This corrected titer is to be used with the tabulated factor]

\begin{tabular}{|c|c|c|c|c|c|c|c|c|c|c|c|c|c|c|}
\hline \multirow{2}{*}{ Titer } & \multirow{2}{*}{$\begin{array}{l}\text { Dex- } \\
\text { trose }\end{array}$} & & \multirow{2}{*}{20} & \multirow{2}{*}{30} & \multirow{2}{*}{40} & \multirow{2}{*}{$\begin{array}{r}\text { Invert } \\
\text { Sugar }\end{array}$} & \multirow{2}{*}{60} & \multirow{2}{*}{70} & \multirow{2}{*}{80} & \multirow{2}{*}{90} & \multirow{2}{*}{$\begin{array}{l}\text { Levu- } \\
\text { lose }\end{array}$} & \multicolumn{3}{|c|}{$\begin{array}{l}\text { Titer correc- } \\
\text { tions }\end{array}$} \\
\hline & & & & & & & & & & & & 1 & 2 & 3 \\
\hline & $\begin{array}{l}120.2 \\
120.2 \\
120.2 \\
120.2 \\
120.3\end{array}$ & $\begin{array}{l}120.9 \\
120.9 \\
120.9 \\
120.9 \\
121.0\end{array}$ & $\begin{array}{l}121 . \\
121 . \\
121 .\end{array}$ & $\begin{array}{l}122.2 \\
122.2 \\
122.2 \\
122.3 \\
122.3\end{array}$ & $\begin{array}{l}122.9 \\
122.9 \\
122.9 \\
123.0 \\
123.0\end{array}$ & $\begin{array}{l}123.6 \\
123.6 \\
123.6 \\
123.7 \\
123.7\end{array}$ & $\begin{array}{l}124.4 \\
124.4 \\
124.4 \\
124.5 \\
124.5\end{array}$ & $\begin{array}{l}125.1 \\
125.1 \\
125.2 \\
125.2 \\
125.3\end{array}$ & $\begin{array}{l}125.9 \\
125.9 \\
125.9 \\
126.0 \\
126.0\end{array}$ & $\begin{array}{l}126.6 \\
126.6 \\
126.7 \\
126.7 \\
126.8\end{array}$ & \begin{tabular}{|l}
127.4 \\
127.4 \\
127.5 \\
127.5 \\
127.6
\end{tabular} & $\begin{array}{r}0.12 \\
.13 \\
.14 \\
.15 \\
.15\end{array}$ & $\begin{array}{l}0.24 \\
.26 \\
.28 \\
.30 \\
.31\end{array}$ & $\begin{array}{l}0 . \\
. \\
:\end{array}$ \\
\hline & $\begin{array}{l}120.3 \\
120.3 \\
120.4 \\
120.4 \\
120.5\end{array}$ & $\begin{array}{l}121.0 \\
121.0 \\
121.1 \\
121.1 \\
121.2\end{array}$ & $\begin{array}{l}121.7 \\
121.7 \\
121.8 \\
121.8 \\
121.9\end{array}$ & $\begin{array}{l}122.5 \\
122.5 \\
122.6\end{array}$ & $\begin{array}{l}123.1 \\
123.1 \\
123.2 \\
123.2 \\
123.3\end{array}$ & $\begin{array}{l}123.8 \\
123.8 \\
123.9 \\
123.9 \\
124.0\end{array}$ & $\begin{array}{l}124.6 \\
124.6 \\
124.7 \\
124.7 \\
124.8\end{array}$ & $\begin{array}{l}125.3 \\
125.4 \\
125.4 \\
125.5 \\
125.5\end{array}$ & $\begin{array}{l}126.1 \\
126.1 \\
126.2 \\
126.2 \\
126.3\end{array}$ & $\begin{array}{l}126.8 \\
126.9 \\
126.9 \\
127.0 \\
127.0\end{array}$ & $\begin{array}{l}127.6 \\
127.7 \\
127.7 \\
127.8 \\
127.8\end{array}$ & .16 & $\begin{array}{l}.33 \\
.34 \\
.36\end{array}$ &. \\
\hline & $\begin{array}{l}120.5 \\
120.6 \\
120.6 \\
120.7 \\
120.7\end{array}$ & $\begin{array}{l}121.3 \\
121.4 \\
121.4\end{array}$ & $\begin{array}{l}122.0 \\
122.1 \\
122.1\end{array}$ & $\begin{array}{l}122.7 \\
122.8 \\
122.8\end{array}$ & $\begin{array}{l}123.3 \\
123.4 \\
123.4 \\
123.5 \\
123.5\end{array}$ & \begin{tabular}{|l|}
124.1 \\
124.2 \\
124.2
\end{tabular} & & $\begin{array}{l}125.7 \\
125.7 \\
125.8\end{array}$ & $\begin{array}{l}126.4 \\
126.5 \\
126.5\end{array}$ & $\begin{array}{l}127.2 \\
127.2 \\
127.3\end{array}$ & & $\begin{array}{r}.23 \\
.24\end{array}$ & $\begin{array}{l}.45 \\
.47\end{array}$ & .7 \\
\hline & $\begin{array}{l}120.8 \\
120.8 \\
120.8 \\
120.9 \\
120.9\end{array}$ & 121.6 & $\begin{array}{l}122.2 \\
122.3 \\
122.3\end{array}$ & $\begin{array}{l}123.0 \\
123.0 \\
123.1\end{array}$ & $\begin{array}{l}123.6 \\
123.7 \\
123.7 \\
123.8\end{array}$ & & $\begin{array}{l}125.1 \\
125.1 \\
125.2 \\
125.2 \\
125.3\end{array}$ & $\begin{array}{l}125.9 \\
125.9 \\
126.0\end{array}$ & $\begin{array}{l}126.7 \\
126.8\end{array}$ & $\begin{array}{l}127.4 \\
127.4 \\
127.5\end{array}$ & & $\begin{array}{l}.27 \\
.28\end{array}$ & $\begin{array}{l}.49 \\
.50 \\
.52 \\
.54 \\
.55\end{array}$ & .8 \\
\hline & $\begin{array}{l}121.0 \\
121.0 \\
121.1 \\
121.2\end{array}$ & $\begin{array}{l}121.8 \\
121.9\end{array}$ & $\begin{array}{l}122.5 \\
122.6\end{array}$ & $\begin{array}{l}123.2 \\
123.3\end{array}$ & $\begin{array}{l}123.9 \\
123.9 \\
124.0\end{array}$ & & $\begin{array}{l}125.3 \\
125.4 \\
125.4 \\
125.5\end{array}$ & $\begin{array}{l}126.1 \\
126.2\end{array}$ & & $\begin{array}{l}127.6 \\
127.7\end{array}$ & & $\begin{array}{r}.30 \\
.31\end{array}$ & $\begin{array}{l}.57 \\
.59 \\
.60 \\
.62\end{array}$ & \\
\hline & $\begin{array}{l}121.2 \\
121.2 \\
121.3 \\
121.4\end{array}$ & $\begin{array}{l}122.0 \\
122.1\end{array}$ & $\begin{array}{l}122.7 \\
122.8\end{array}$ & $\begin{array}{l}123.4 \\
123.5\end{array}$ & $\begin{array}{l}124.1 \\
124.2\end{array}$ & \begin{tabular}{|l|}
124.8 \\
124.9
\end{tabular} & $\begin{array}{l}125.6 \\
125.6\end{array}$ & $\begin{array}{l}126.3 \\
126.4\end{array}$ & $\begin{array}{l}127.1 \\
127.1\end{array}$ & $\begin{array}{l}127.8 \\
127.9\end{array}$ & $\begin{array}{l}128.6 \\
128.6\end{array}$ & $\begin{array}{l}.33 \\
.34\end{array}$ & $\begin{array}{l}.63 \\
.65 \\
.67 \\
.68\end{array}$ & $\begin{array}{r}.9 \\
.9 \\
1.0 \\
1.0\end{array}$ \\
\hline & $\begin{array}{l}121.4 \\
121.5 \\
121.5 \\
121.6\end{array}$ & $\begin{array}{l}122.1 \\
122.2 \\
122.2 \\
122.3\end{array}$ & $\begin{array}{l}122.8 \\
122.9 \\
122.9 \\
123.0\end{array}$ & 123.7 & $\begin{array}{l}124.3 \\
124.3 \\
124.4\end{array}$ & 125.1 & $\begin{array}{l}125.8 \\
125.8\end{array}$ & 126.6 & $\begin{array}{l}127.2 \\
127.3 \\
127.3\end{array}$ & $\begin{array}{l}128.0 \\
128.1\end{array}$ & $\begin{array}{l}128.7 \\
128.7 \\
128.8 \\
128.8\end{array}$ & $\begin{array}{l}.35 \\
.36 \\
.37 \\
.37\end{array}$ & $\begin{array}{r}.70 \\
.72 \\
.73 \\
.75\end{array}$ & $\begin{array}{l}1.0 \\
1.0 \\
1.1 \\
1.1\end{array}$ \\
\hline & $\begin{array}{l}121.6 \\
121.7 \\
121.7 \\
121.8\end{array}$ & $\begin{array}{l}122.3 \\
122.4 \\
122.4 \\
122.5\end{array}$ & $\begin{array}{l}123.0 \\
123.1 \\
123.1 \\
123.2\end{array}$ & $\begin{array}{l}123.8 \\
123.8 \\
123.9\end{array}$ & $\begin{array}{l}124.4 \\
124.5 \\
124.5 \\
124.6\end{array}$ & $\begin{array}{l}125.2 \\
125.2 \\
125.3\end{array}$ & $\begin{array}{l}125.9 \\
125.9 \\
126.0 \\
126.0\end{array}$ & $\begin{array}{l}126.6 \\
126.7 \\
126.7 \\
126.8\end{array}$ & $\begin{array}{l}127.4 \\
127.4 \\
127.5 \\
127.5\end{array}$ & $\begin{array}{l}128.2 \\
128.3\end{array}$ & $\begin{array}{l}128.9 \\
128.9 \\
129.0 \\
129.0\end{array}$ & $\begin{array}{r}.38 \\
.39 \\
.40 \\
.41\end{array}$ & $\begin{array}{l}.76 \\
.78 \\
.80 \\
.81\end{array}$ & $\begin{array}{l}1.17 \\
1.20 \\
1.22\end{array}$ \\
\hline
\end{tabular}


TABLE 23.-Copper-levulose equivalents according to Jackson and Mathews's modification of Nyns's selective method for levulose

[All data expressed in milligrams]

\begin{tabular}{|c|c|c|c|c|c|c|c|c|c|c|c|c|c|c|c|}
\hline $\mathrm{Cu}$ & $\begin{array}{l}\text { Levu- } \\
\text { lose }\end{array}$ & $\mathrm{Cu}$ & $\begin{array}{c}\text { Levu- } \\
\text { lose }\end{array}$ & $\mathrm{Cu}$ & $\begin{array}{l}\text { Levu- } \\
\text { lose }\end{array}$ & $\mathrm{Cu}$ & $\begin{array}{l}\text { Levu- } \\
\text { lose }\end{array}$ & $\mathrm{Cu}$ & $\begin{array}{l}\text { Levu- } \\
\text { lose }\end{array}$ & $\mathrm{Cu}$ & $\begin{array}{l}\text { Levu- } \\
\text { lose }\end{array}$ & $\mathrm{Cu}$ & $\begin{array}{l}\text { Levu- } \\
\text { lose }\end{array}$ & $\mathrm{Cu}$ & $\begin{array}{l}\text { Levu- } \\
\text { lose }\end{array}$ \\
\hline 1 & 0.6 & 40 & 13.9 & 79 & 25.1 & 118 & 36.0 & 157 & 46.6 & 196 & 56.8 & 235 & 67.9 & 274 & 80.4 \\
\hline 2 & 1. 1 & 41 & 14. 2 & 80 & 25.4 & 119 & 36.2 & 158 & 46. 9 & 197 & 57.1 & 236 & 68. 2 & 275 & 80.7 \\
\hline 3 & 1. 6 & 42 & 14.5 & 81 & 25.7 & 120 & 36.5 & 159 & 47.1 & 198 & 57.3 & 237 & 68.5 & 276 & 81.0 \\
\hline 4 & 2. 1 & 43 & 14.8 & 82 & 25.9 & 121 & 36.8 & 160 & 47.4 & 199 & 57. 6 & 238 & 68.8 & 277 & 81.4 \\
\hline 5 & 2.5 & 44 & 15. 1 & 83 & 26.2 & 122 & 37.1 & 161 & 47.7 & 200 & 57.9 & 239 & 69.1 & 278 & 81.7 \\
\hline 6 & 2.9 & 45 & 15.4 & 84 & 26.5 & 123 & 37.3 & 162 & 47.9 & 201 & 58.1 & 240 & 69.4 & 279 & 82.0 \\
\hline 7 & 3.3 & 46 & 15. 7 & 85 & 26.8 & 124 & 37.6 & 163 & 48.2 & 202 & 58.4 & 241 & 69.7 & 280 & 82.4 \\
\hline 8 & 3.7 & 47 & 16.0 & 86 & 27.0 & 125 & 37 & 164 & 48.4 & 203 & & 242 & 70.0 & 281 & 82.7 \\
\hline 9 & 4. 1 & 48 & 16.3 & 87 & 27.3 & 125 & 38.2 & 165 & 48.7 & 204 & 58.9 & 243 & 70.3 & 282 & 83. 1 \\
\hline 10 & 4.5 & 49 & 16. 6 & 88 & 27.6 & 127 & 38.5 & 166 & 49.0 & 205 & 59.2 & 244 & 70.7 & 283 & 83.4 \\
\hline 11 & 4.8 & 50 & 16.8 & 89 & 27.9 & 128 & 38.7 & 167 & 49.2 & 206 & 59.4 & 245 & 71.0 & 284 & 83.8 \\
\hline 12 & 5.1 & 51 & 17. 1 & 90 & 28.1 & 129 & & 168 & & 207 & & 246 & & 285 & 84. 1 \\
\hline 13 & 5.5 & 52 & 17.4 & 91 & 28.4 & 130 & 39.3 & 169 & 49.7 & 208 & 60.0 & 247 & 71 & 286 & 84.4 \\
\hline 14 & 5.9 & 53 & 17. 7 & 92 & 28.7 & 131 & 39.6 & 170 & 50.0 & 209 & 60.3 & 248 & 71.9 & 287 & $\begin{array}{l}0.4 .4 \\
84.8\end{array}$ \\
\hline 15 & 6. 2 & 54 & 18.0 & 93 & 29.0 & 132 & 39.9 & 171 & 50.2 & 210 & 60.6 & 249 & 72.2 & 238 & 85.1 \\
\hline 16 & 6.5 & 55 & 18. 3 & 94 & 29.2 & 133 & 40 & 172 & 50 & 211 & 60 & 250 & 72 & 289 & 35.5 \\
\hline 17 & 6. 9 & 56 & 18. 6 & 95 & 29.5 & 134 & 40 & 173 & 50 & 212 & 61 & 251 & & 290 & 9 \\
\hline 18 & 7. 2 & 57 & 18. 9 & $90^{\circ}$ & 29.8 & 135 & 40.7 & 174 & 51.0 & 213 & 61.4 & 252 & 73. 1 & 291 & 86. 2 \\
\hline 19 & 7.6 & 58 & 19.1 & 97 & 30.1 & 136 & 40. & 175 & 51.3 & 214 & 61. & 253 & 73.5 & 292 & 86.6 \\
\hline 20 & 7.9 & 59 & 19.4 & 98 & 30.4 & 137 & 41.2 & 176 & 51.5 & 215 & 62.0 & 254 & 73.8 & 293 & 86.9 \\
\hline 21 & 8.2 & 60 & 19. 7 & 99 & 30.7 & 138 & 41 & 177 & 51. & 216 & 62. & 255 & 74 & 294 & 87.3 \\
\hline 2 & 8.5 & 61 & 20.0 & 100 & 3 & 139 & & 178 & & 217 & & 256 & & 295 & 87.6 \\
\hline 23 & 8.9 & 62 & 20.3 & 101 & 31.2 & 140 & 42 & 179 & 52.3 & 218 & 62 & 257 & 74 & 296 & 83. 0 \\
\hline 24 & 9.2 & 63 & 20.6 & 102 & 31.5 & 141 & 42 & 180 & & 219 & & 258 & & 297 & 88.4 \\
\hline 25 & 9.5 & 64 & 20.9 & 103 & 31.8 & 142 & 42.6 & 181 & 52.8 & 220 & 63.4 & 259 & 75.4 & 298 & 88.7 \\
\hline 26 & 9. & 65 & 21.2 & 104 & 32 & 143 & 42 & 182 & 53 & 221 & 63 & 260 & 75 & 299 & 89. \\
\hline 27 & 10.1 & 66 & 21.4 & 105 & 32 & 144 & 45 & 183 & 5 & 222 & 64 & 261 & & 300 & 89.5 \\
\hline 28 & 10.4 & 67 & 21.7 & 106 & & 145 & & 184 & & 223 & & 262 & & 301 & 89.8 \\
\hline 29 & 10.7 & 68 & 22.0 & 107 & 32.9 & 146 & 43 & 185 & 53. 9 & 224 & 64. 6 & 263 & 76.7 & 302 & 90.2 \\
\hline 30 & 11. 0 & 69 & 22.2 & 108 & 33.2 & 147 & 43.9 & 186 & 54.2 & 225 & 64.9 & 264 & 77.0 & 303 & 90.5 \\
\hline 31 & 11. 3 & 70 & 22.5 & 109 & 33. & 148 & 44 & 187 & 54 & 226 & 65 & 265 & 77 & 304 & 90.9 \\
\hline 32 & & 71 & & 110 & & 149 & & 188 & & 227 & & 266 & & 305 & 91.3 \\
\hline 33 & 11.9 & 72 & 23. 1 & 111 & 34.0 & 150 & 44 & 189 & 54 & 228 & 65 & 267 & & 306 & 91. 7 \\
\hline 34 & 12. 2 & 73 & 23.4 & 112 & 34 & 151 & 45 & 190 & 55 & 229 & 66 & 268 & 78 & 307 & 92.0 \\
\hline 35 & 12.5 & 74 & 23.7 & 113 & 34.6 & 152 & 45.3 & 191 & 55.5 & 230 & 66.4 & 269 & 78.7 & 308 & 92.4 \\
\hline 36 & 12. & 75 & 24 & 11 & 34 & 15 & 4 & 192 & 55 & 23 & $6 f$ & 270 & 79 & 309 & 92.8 \\
\hline 37 & 13. 1 & 76 & 24. 2 & 115 & 35 & 154 & 45 & 193 & 56 & 232 & 67 & 271 & & 310 & 93. 2 \\
\hline 38 & 13.4 & 77 & 24.5 & 116 & 35.4 & 155 & 46. & 194 & 56.3 & 233 & 67.3 & 272 & 79.7 & 311 & 93.5 \\
\hline 39 & 13.7 & 78 & 24.8 & 117 & 35.7 & 156 & 46.4 & 195 & 56.5 & 234 & 67.6 & 273 & 80.0 & 312 & 93.9 \\
\hline
\end{tabular}

Example illustrating the use of Table 24 (see discussion, p. 433).Assume that a solution of levulose and dextrose polarized at $20^{\circ} \mathrm{C}$. $-43.8^{\circ} \mathrm{S}$., and that $5 \mathrm{ml}$ of this solution diluted to $100 \mathrm{ml}$ gave a Lane and Eynon titration of $26.18 \mathrm{ml}$ when the correction for the titration factor is zero. Then

and

$$
D=100 / 5=20
$$

$$
\frac{P T}{D}=-\frac{43.8 \times 26.18}{20}=-57.3 \text {. }
$$

By Table 24 the approximate ratio is 89.8 per cent, and the correction factor, $f$, is -0.80 . The correction is

$$
\frac{f \times D}{T}=-\frac{0.80 \times 20}{26.18}=-0.6
$$

and the true ratio is

$$
89.8-0.6=89.2
$$


The concentration of total sugar is calculated in the usual way from the titer

$$
\frac{100 F}{T}=\frac{100 \times 127.0}{26.18}=485.1 \mathrm{mg} \text { per } 100 \mathrm{ml} \text { of solution titrated }
$$

The concentration in the polarized solution is

$$
0.4851 \times 20=9.702 \mathrm{~g} \text { per } 100 \mathrm{ml}
$$

and levulose is

$$
9.702 \times 89.2 \text { per cent }=8.654 \mathrm{~g} \text { per } 100 \mathrm{ml} .
$$




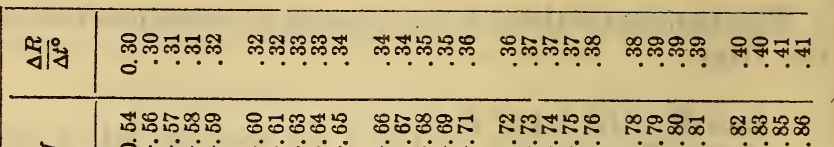
ilii ilil ilil ilil lili ili

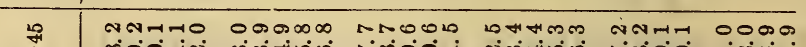

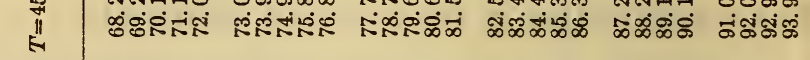

\begin{tabular}{|c|c|c|c|c|c|c|}
\hline II & 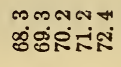 & 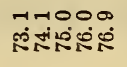 & 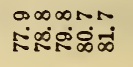 & 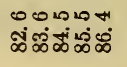 & 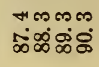 & 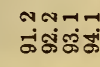 \\
\hline เุ & & & & $N$ & On & \\
\hline
\end{tabular}

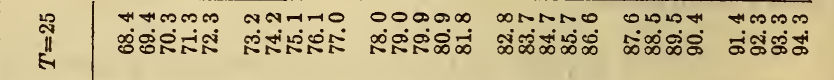

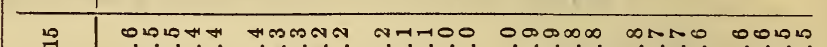

II

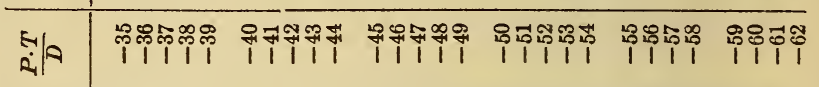

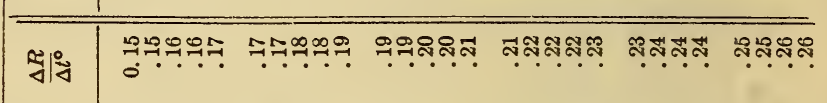

\begin{tabular}{|c|c|c|c|c|c|c|}
\hline- & 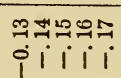 & 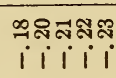 & 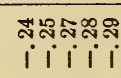 & 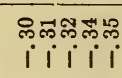 & 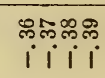 & $\begin{array}{l}\text { 와워연 } \\
\text { i门i }\end{array}$ \\
\hline
\end{tabular}

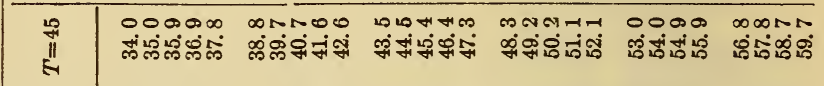

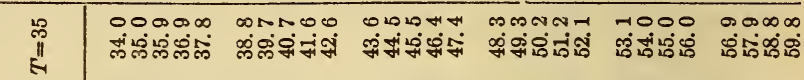

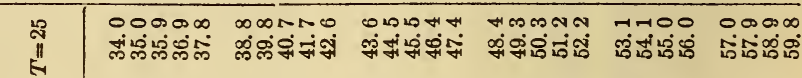

आ|

ह

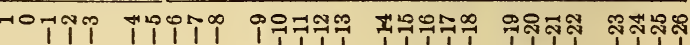

4.

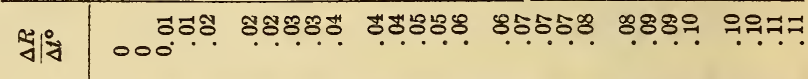

\begin{tabular}{|c|c|c|c|c|c|c|}
\hline- & 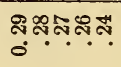 & ఇสุสจำ & 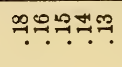 & 궁ㅇㅇㅇㅇ & 부융요. & 080. \\
\hline है। & $\begin{array}{l}\text { Nonro } \\
\text { iotivion }\end{array}$ & 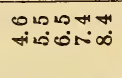 & 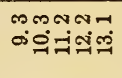 & 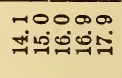 & 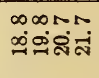 & 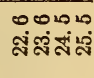 \\
\hline in & món & 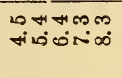 & 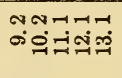 & 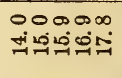 & 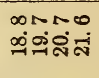 & 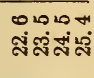 \\
\hline 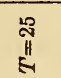 & 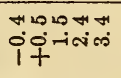 & 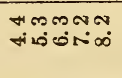 & 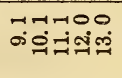 & 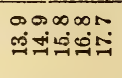 & 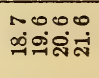 & 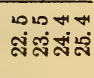 \\
\hline in & 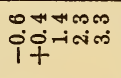 & 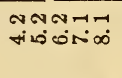 & 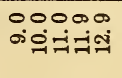 & 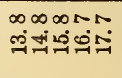 & $\begin{array}{l}0000 \\
\text { ๓๐ंสี่ }\end{array}$ & 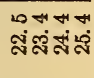 \\
\hline E. & 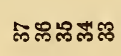 & న్లెడ్లినిని & ลีสัสిสีన & สีสన్సి & 두욤ㅍ & ๓ㄱㄱㄱ \\
\hline
\end{tabular}




\begin{tabular}{|c|c|}
\hline ุำำษ & 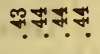 \\
\hline $\begin{array}{l}\infty \\
\text { i } \\
i \text { i i }\end{array}$ & 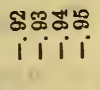 \\
\hline 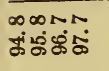 & 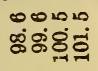 \\
\hline 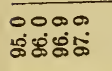 & $\begin{array}{l}\infty \infty \pi \\
\infty \dot{\delta} \delta \dot{\delta}-\dot{0}\end{array}$ \\
\hline 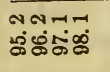 & 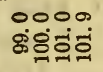 \\
\hline मூங் & 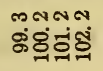 \\
\hline ஜீீீ丨 & 뚱유요 \\
\hline ลิลลั. & ำㅉํำ \\
\hline 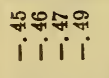 & 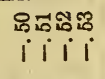 \\
\hline 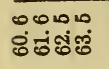 & 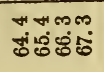 \\
\hline 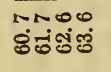 & 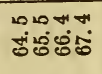 \\
\hline $\begin{array}{l}\infty N \mathbf{r} \\
\dot{8} \text { ச் }\end{array}$ & 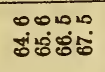 \\
\hline 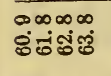 & 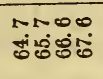 \\
\hline 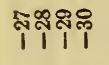 & ఝొన్ణ \\
\hline 곡ำำ & ஐே゙ザ \\
\hline $\begin{array}{l}8085 \\
\text { i1 }\end{array}$ & 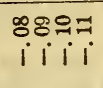 \\
\hline 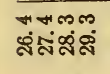 & 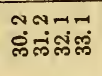 \\
\hline 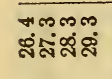 & 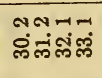 \\
\hline 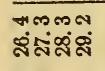 & 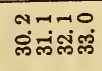 \\
\hline 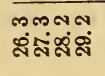 & Nָషઆం \\
\hline$\infty \infty N \infty$ & מ \\
\hline
\end{tabular}


Example illustrating the use of Table 25 (see discussion, p. 434).Assume that a solution of levulose and dextrose gave a Lane and Eynon titer of $25.89 \mathrm{ml}$ and that $20 \mathrm{ml}$ of the same solution precipitated $247.3 \mathrm{mg}$ of copper by the modified Nyns method. The original solution then contained by Table $23 \frac{100 \times 71.7}{20}=358.5 \mathrm{mg}$ of apparent levulose per $100 \mathrm{ml}$. Then

$$
\frac{T \times l}{100}=\frac{25.89 \times 358.5}{100}=92.8
$$

Referring to Table 25 we find opposite this product and under $T=25$ the true ratio of levulose to total sugar to be 71.5 per cent. Lane and Eynon's factor is 125.7 and the total sugar per $100 \mathrm{ml}$ is $\frac{125.7}{25.89}=485.5 \mathrm{mg}$, of which 71.5 per cent $=347.1 \mathrm{mg}$ is levulose and $138.4 \mathrm{mg}$ is dextrose.

TABLE 25.-Ratio of levulose to total sugar from Lane and Eynon titration and Nyns "apparent" levulose

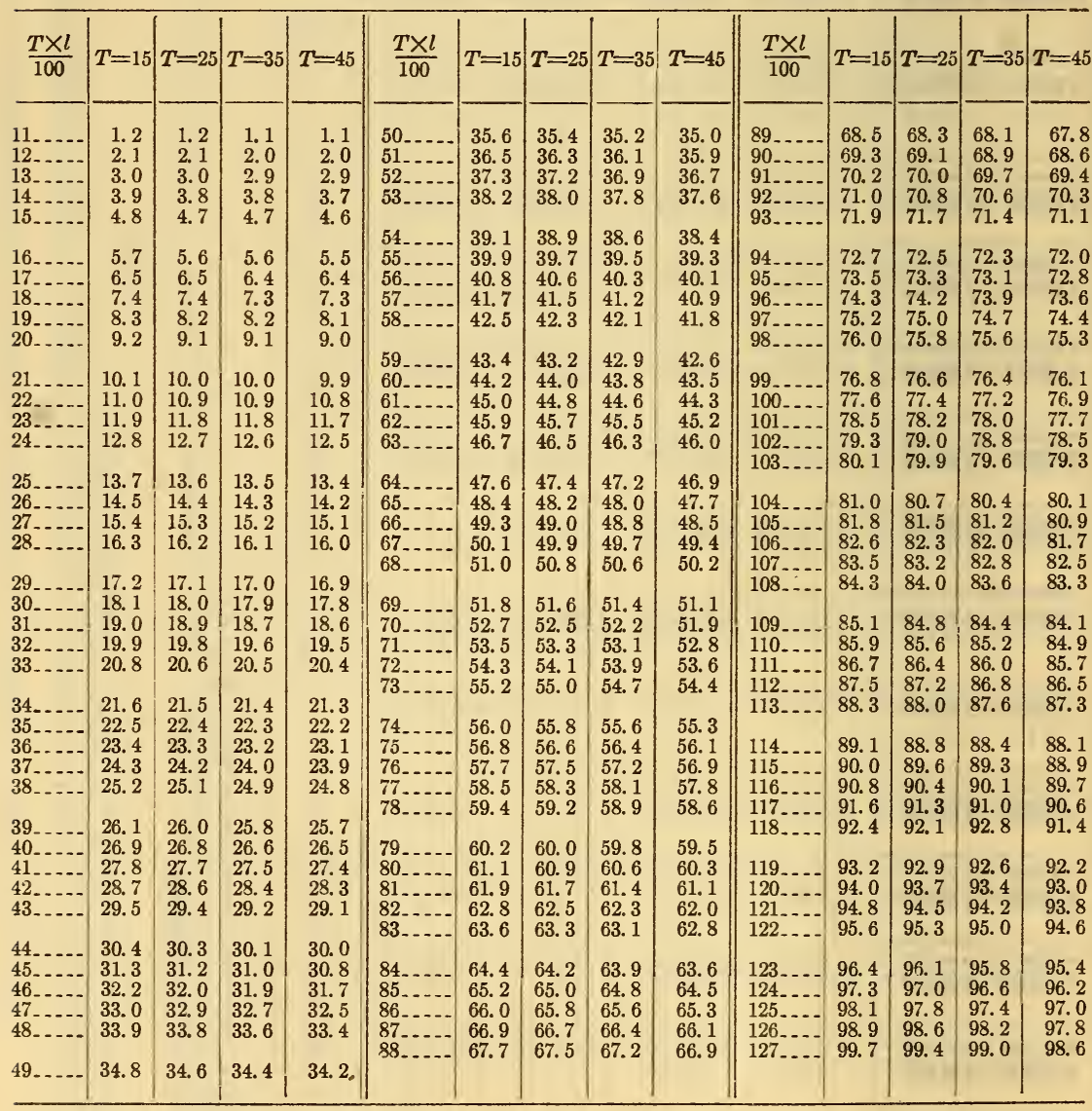

WASHINGTON, January 27, 1932. 